\title{
The Effect of Family Control on Firm Value and Performance: Evidence from Continental Europe
}

\section{Roberto Barontini}

Scuola Superiore Sant'Anna, P.zza Martiri della Libertà 33, 56127 Pisa, Italy. e-mail r.barontini@sssup.it

\section{Lorenzo Caprio}

Università Cattolica del Sacro Cuore, Largo Gemelli 1, 20123 Milano, Italy. e-mail lorenzo.caprio@unicatt.it

\begin{abstract}
We investigate the relation between ownership structure and firm performance in Continental Europe, using data from 675 publicly traded corporations in 11 countries. Although family-controlled corporations exhibit larger separation between control and cash-flow rights, our results do not support the hypothesis that family control hampers firm performance. Valuation and operating performance are significantly higher in founder-controlled corporations and in corporations controlled by descendants who sit on the board as non-executive directors. When a descendant takes the position of CEO, family-controlled companies are not statistically distinguishable from non-family firms in terms of valuation and performance.
\end{abstract}

Keywords: ownership structure, corporate governance, family firms

JEL codes: G32, G34.

\section{Introduction}

The effect of family control of public corporations is a growing field of interest in the finance and management literature. In this paper we address the point by studying a sample of 675 large public corporations in continental Europe.

We are grateful to Massimo Belcredi, Magda Bianco, Vincenzo Capizzi, Guido Corbetta, Ettore Croci, Mara Faccio, David Hillier, Anete Pajuste, Belen Villalonga, Dariusz Wójcik, and participants to the EFM Symposium on 'Corporate Governance' in Leeds (April 2005), to the EFA Annual Meeting in Moscow (August 2005), to the CEIS Symposium in Roma-Tor Vergata University (December 2005) to the EIASM workshop on "Family Firms Management Research" in Nice (June 2006), and to the conference on "Corporate Governance in Family/Unlisted Firms" in Thun (June 2006) for stimulating comments. The responsibility for any remaining errors rests fully with the authors. The research project has been funded by MIUR, COFIN 2003. 
Family control of public corporations is considered with mixed feelings by European public opinion. On one hand, it is respected because many large European companies have prospered under the founding family for a long time, sometimes for centuries, thereby accrediting the view that families are long-term investors committed to the success of the firm they invest in. On the other hand, the different priorities that families may have with respect to those of outside shareholders are seen as a potential for conflicts of interest that may hinder value creation and the growth of European companies. Families are clearly oriented to maintaining control of the companies they found or acquire, and often resort to control-enhancing devices (dual-class shares, pyramid, etc.) that several studies have proven to be associated with lower value-creation (Claessens et al., 2002; Lins, 2003; Gompers et al., 2004), and that many critics would like to see banned by EC regulation (see the EC 'High Level Group of Company Law Experts' report, also known as the Winter report, HLG, 2002 a,b). Families are often accused of considering executive positions in the firm as a channel for providing highlyremunerated jobs to the offspring, thereby depriving outside shareholders of the valuecreation potential that the selection of the best managers would provide.

Since family control can have both positive and negative properties, empirical evidence is of paramount importance for judging its final effect and for orienting regulation. Empirical literature about family control of public corporations has been rather focused on the USA, starting from Shleifer and Vishny (1986) and Morck et al. (1989). After them, Denis and Denis (1994) study majority-owned firms, and find that they do not exhibit specific inefficiency features although most of them are characterised by family involvement. Many papers highlight that founder-CEOs have a positive effect on corporate performance (McConnaughy et al., 1998; Palia and Ravid, 2002; Anderson and Reeb, 2003; Adams et al., 2004; Fahlenbrach, 2005; Villalonga and Amit, 2006). A critical event for family control is clearly the retirement of the founder coupled to the 'passing of the baton' to an heir.This often leads to a decline in the performance of the firm (McConnaughy et al., 1998; Pérez-González, 2006; Villalonga and Amit, 2006; for Canada, Morck et al., 2000). On balance, Anderson and Reeb (2003) suggest that family ownership is an effective organisational structure in the USA while Villalonga and Amit (2004) report that family control exhibits specific weaknesses when descendants are involved in top management.

There is little comprehensive evidence concerning European corporations. The only paper similar to ours is Maury (2006), who provides results that are close to those we report in Section 4A, while the results of single-country studies (Gorton and Schmid, 2000; Volpin, 2002; Cronqvist and Nilsson, 2003; Sraer and Thesmar, 2004; Hillier and McColgan, 2004; Ehrhardt et al., 2006) give rise to a contrasted picture about the effect of family control. To our knowledge, our paper is the first one to document the consequences of family control at the founder and descendants stage across continental Europe.

The evidence we obtain sheds light on a positive association of family control with market valuation and operating performance. The intriguing feature of our results is that families are the type of owners that most often resort to control-enhancing devices associated with lower performance, yet there is no evidence that family control is negative for firm value and operating performance. If we consider both family affiliation and the percentage of cash-flow and voting rights held by the largest shareholder, the effect of family control is positive, suggesting that for any given cash-flow/voting rights combination, families tend to be better than other types of controlling shareholders. If we put together the effect of family control with the ownership structure chosen by families, we find that part of the positive effect is wasted by the over use of 
wealth-reducing control-enhancing devices, but a residual positive effect is clearly still there. Thus, our results provide a contribution to the existing literature by warning that the simple observation of the over use of control-enhancing devices by family firms does not imply a global negative effect of family control, as is often assumed.

We then move to consider what happens to family firms' performance when the company is still run by its founder or by the descendants, and what is the role that founders and/or descendents take up in the corporation. We find a confirmation of the non-European results on the positive effect of founders. However, there is no evidence at all that descendant-controlled corporations underperform non-family firms. On the contrary, family firms remain better than non-family ones when descendants limit themselves to the role of non-executive directors, and are not worse than non-family firms when a descendant takes the helm.

\section{Sample Selection and Data}

\section{A. Sample selection}

Faccio and Lang (2002), in their study on ownership structure in Western Europe, analyse a sample of 5,547 Worldscope corporations, roughly corresponding to the universe of stock market listed corporations in 13 countries. We consider only non-financial (SIC 6000-6999) and non-regulated (SIC 4900-4999) corporations in continental Western European countries. We exclude Ireland and the UK because their corporations are commonly considered to follow a different - 'anglo-saxon' and more 'shareholdervalue-oriented' - style of management, and Faccio and Lang show in these two countries family control is less important than in Continental Europe. Therefore, we select corporations from 11 countries (Belgium, Denmark, Finland, France, Germany, Italy, the Netherlands, Norway, Spain, Sweden and Switzerland). ${ }^{1}$ This leaves us with 2,631 Worldscope corporations. Given the amount of data needed for the present study, we focus our attention on relatively larger companies - with assets worth more than $€ 300$ million as of the end of year 1999 - on the assumption that more information can be found for them at reasonable cost. After this, we are left with 853 corporations that become 675 after excluding companies in which the largest shareholder holds more than $95 \%$ of the share capital, limited liability partnerships, and dual class corporations in which only one class is publicly traded.

In Table 1 we present the number of corporations in the sample by year, country and industry (using Campbell's (1996) classification of industries). The 675 corporations in 1999 decrease to 640 in 2000 and 606 in 2001 because of mergers, privatisations and bankruptcies. The breakdown by countries shows that the largest number of corporations belong to France (144 in 1999, or $21.3 \%$ of the total) and not to Germany $(119,17.5 \%)$, by far the largest economy of the area. Three countries, the Netherlands, Italy and Switzerland, weigh in the sample around $10 \%$, the others around $5 \%$.

\footnotetext{
${ }^{1}$ Of the continental Western European countries, we do not consider Austria, Greece, Luxemburg and Portugal. For Austria, Luxemburg and Portugal, preliminary research showed that inclusion would have increased the sample size to a negligible extent. We included corporations of Greece at an early stage of the research, but we realised that during the period covered by the study this country's firms experienced a major change in accounting rules, which made comparison difficult.
} 
Finally, the breakdown of the corporations by industries shows a fairly widespread distribution. Basic industry (14.3\%), consumer durables $(12.2 \%)$ and capital goods $(11.5 \%)$ are the most represented industries.

\section{B. The construction of the dataset}

Given the objectives of the paper, we can divide the variables forming the dataset in three groups; i) ownership, ii) valuation and iii) control variables. The measures of these variables are collected for the years 1999, 2000 and 2001.

$i$. Ownership variables. The identity of the ultimate largest shareholder and the size of its cash-flow and voting rights are detected according to the standard methodology developed by La Porta et al. (1999), and followed by Claessens et al. (2000), Faccio and Lang (2002), Claessens et al. (2002), to whom we refer for a more in-depth description.

To do this, we work on (1) official registers held by stock market authorities, and (2) information disclosed by the corporations, either in the 'investor relation' section of their websites, or in their annual reports. If we find all the information needed in (1) or (2) we end the search for data about ownership. Other reliable sources of information were considered (3) Worldscope, Extel and Osiris, (4) information contained in the various national annual directories of listed companies published privately, (5) information contained in the financial press, that we obtain both through Lexis-Nexis and web-search engines. For sources 3-5 we considered the information valid if confirmed by two different sources. In Appendix A we make a list of sources used by country.

The starting point for the ownership variables are thus the Direct voting rights and Direct cash-flow rights held by the largest shareholders, ${ }^{2}$ which are two different figures in the case of a share capital structure departing from one share/one vote. ${ }^{3}$ We then trace the map of the ownership of the stakes, in order to identify the ultimate shareholders and their ultimate ownership of voting rights and cash-flow rights. Therefore, the Ultimate cash-flow rights are those held by the largest shareholder after taking into account the whole chain of control ${ }^{4}$ (if family A owns $50 \%$ of direct cash-flows of B and B owns $40 \%$ of direct cash-flows of C, family A owns ultimately $50 \%{ }^{*} 40 \%=20 \%$ of cash-flows of C) and Ultimate voting rights are the voting rights held in the weakest link of the control chain. $10 \%$ is the cut off point for the existence of a control chain, in the sense that a listed company that has no shareholder larger than $10 \%$ is considered widely held and therefore not controlled (however, it can be the apex of a control chain).

We collect from the above mentioned sources some additional information about corporate governance, concerning: the size and composition of the board, ${ }^{5}$ with a separate indication of executive and non-executive directors; the number of members of

\footnotetext{
${ }^{2}$ The detail of mandatory disclosure about the minimum size of shareholdings varies between $2 \%$ and $5 \%$ across countries. We collect the largest three available, whatever the national regulation. In doing this, we sum up the direct shareholdings pertaining to a single ultimate owner, even if they are held through different juridical subjects.

${ }^{3}$ We take into account the special case of France, where it is possible for 'stable' shareholders to obtain two votes for each share held. We collect the information about double votes from annual reports.

${ }^{4}$ We also consider multiple control chains and cross-holdings in the sense defined by Faccio and Lang (2002).

${ }^{5}$ Or of the two boards, in countries where dual boards are mandatory (Germany and the Netherlands) or eligible (Finland and France).
} 


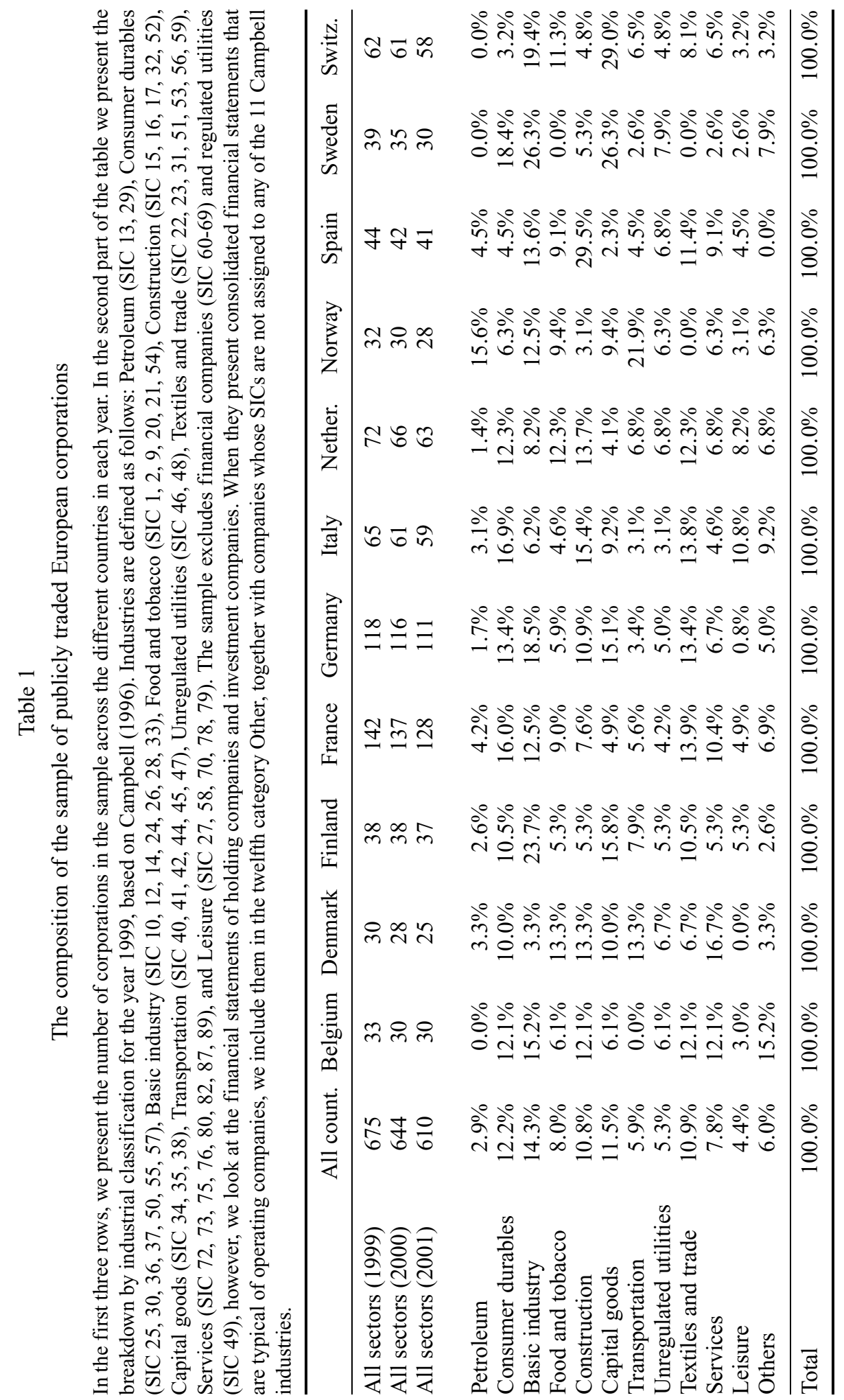


the board belonging to the controlling family, when there is one; in this case, whether the founder is still alive and has a role on the board, or the family members controlling the company have to be classified as descendants. To obtain the latter variable we have to perform a particularly careful scrutiny of the documentation supplied by family companies on their websites, and of information available through the press.

ii. Valuation variables. The valuation and operating performance variables we employ are Tobin's Q and the accounting Return on Assets (ROA) measured at the end of 1999, 2000 and 2001.

As for the measure of Tobin's Q, we start from the usual ratio between (Book value of total assets - Book value of shareholders' equity + Market value of shareholders' equity) and (Book value of total assets). However, we observe that in our sample full consolidation of the financial statements of controlled companies is the norm. Therefore, to correct for the underestimation of Tobin's Q induced by valuation of 'minority interests' at their book value, we multiply the book value of this item by the market-to-book multiple of the company's 'shareholders' equity'.

ROA is defined as the ratio between 'operating profit' and 'total assets' (both variables are taken as supplied by Worldscope), but we deduct from 'total assets', for consistency, the two items 'cash and short-term investments' and 'investment in associated companies'.

iii. Control variables. In regression analysis we employ the following control variables that are standard in the literature: the Industry in which each firm operates (two-digit SIC code); the Size of the corporation, measured by total assets (in the regressions, the logarithm of); a Growth variable, the percentage increase in sales in the previous year; and Leverage, defined as the book value of total financial debt divided by the book value of equity at the end of each year.

\section{Descriptive Statistics}

In this section we present descriptive statistics for the variables we employ in the regression analysis discussed in the following Section 4. In part A we focus on the concentration of voting rights and cash-flow rights, and in part B on the descriptive evidence of family control.

\section{A. Ownership concentration}

In Table 2 we present descriptive statistics for some of the variables of most interest by country (data for year 1999). In the upper part of the table we present the average and median values of the ultimate voting and cash-flow rights of the largest shareholder in the 675 companies (1999). In line with Barca and Becht (2001) and Faccio and Lang (2002), European companies exhibit ownership patterns that are among the most concentrated in the world, even after discarding the smallest caps as we do: in our total sample half of the companies have a shareholder with more than $37 \%$ of the ultimate voting rights.

The difference between the share of voting and cash-flow rights of the largest shareholder, arising from both dual-class shares and pyramiding, is also relevant though not huge (the median is $8.5 \%$ ). 


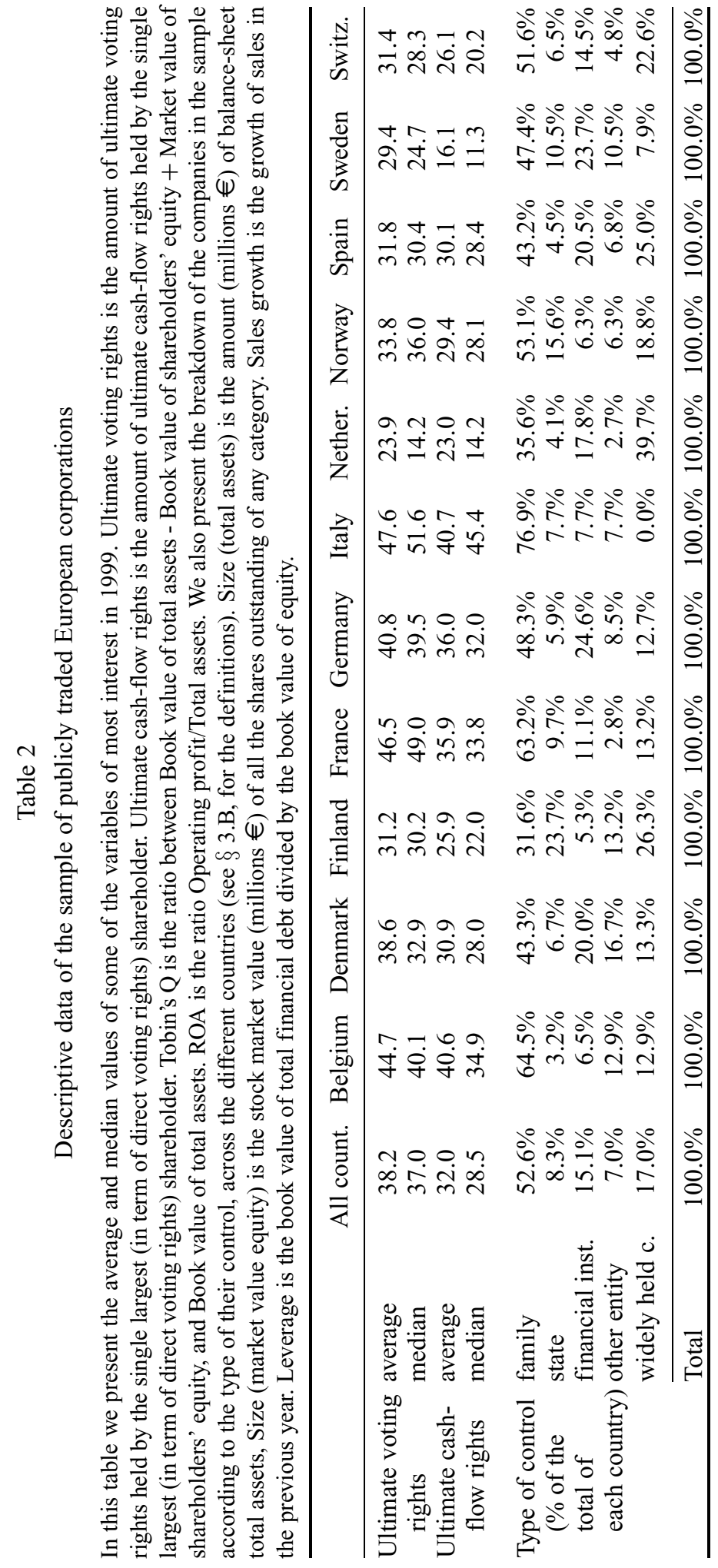




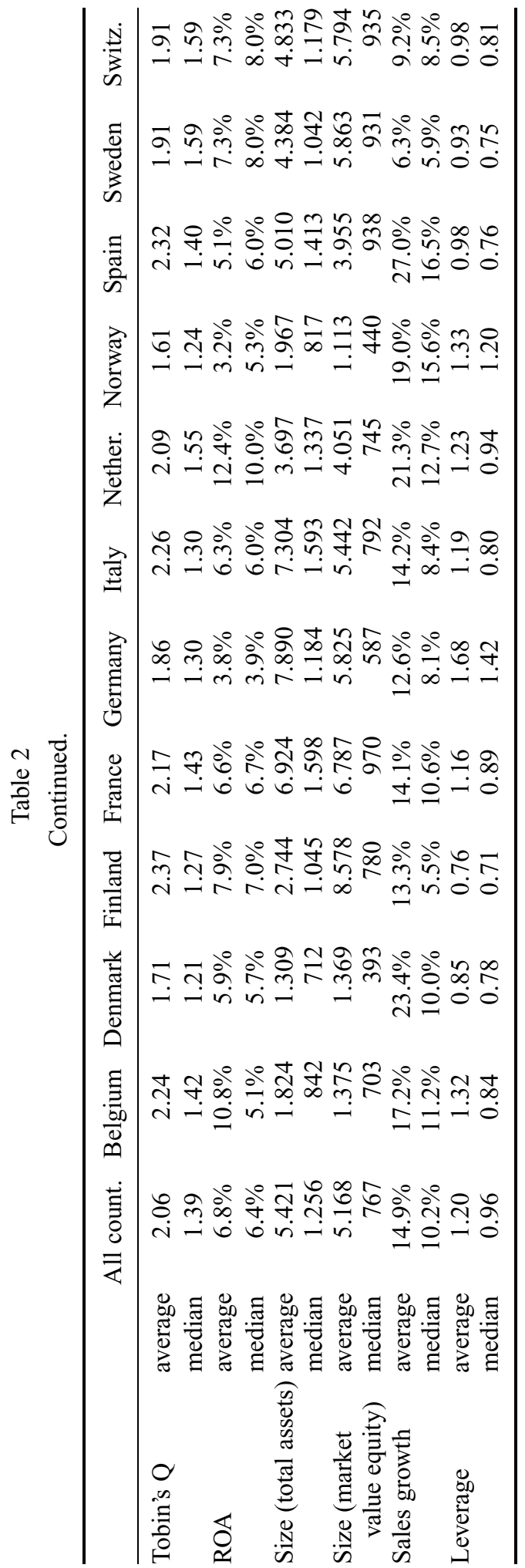


In the table we also present the proportions of companies by the various types of largest shareholder. Families are by far the most frequent largest shareholder $(52.3 \%)$, followed by widely held corporations ${ }^{6}(16.9 \%)$, financial institutions $(15 \%)$, the State $(8 \%)$, and other entities $(6.9 \%)$.

\section{B. Family control}

In Table 3 we present summary statistics about the type of largest shareholder (Panel A), and about the involvement in the corporations of families (Panels B and C). In Panel A, corporations are grouped into the five traditional categories Widely held, Family, State, Financial and Other. We have already observed the prevalence of family as the largest shareholder, this is clearly visible in the first column of Table 3.

In the second and third column, average Tobin's Q and ROA for each class are presented. No clear pattern emerges from their observation, and we can anticipate that some of the inferences that could be suggested by these first figures are not confirmed by the regression results. More relevant is actually the evidence about the average size of the corporations across the different groups, where it is clear that family control is more diffused in comparatively smaller firms.

The remaining columns are about the degree of separation between control and ownership across the different groups. Family- and state-controlled firms are those where the largest shareholder invests more, on average more than one third of the total shareholder capital in terms of ultimate cash-flow rights. But, what better distinguishes family corporations is their larger wedge between voting and cash-flow rights, higher than $10 \%$. Actually, for the majority of the family corporations in our sample (close to $57 \%$ of them) we find that some control-enhancing device is in place.

In Panels B and C of Table 3 we present descriptive statistics about the involvement of families in the management of corporations. Beginning from now, we refer to the strict definition of family firm that we shall employ in the regression analysis presented in the following sections. By this definition, it is not enough that the largest shareholder at the $10 \%$ cut-off is a family (this is the only requirement for inclusion in the group of 355 family-controlled corporations in Panel A) but it must also be true that either the family controls more than $51 \%$ of direct voting rights, or controls more than the double the direct voting rights of the second largest shareholder. We employ this definition to obtain clearer evidence about the possible negative effect of family control, often echoed in popular opinion in Europe, because we realise that in several corporations a family is actually the largest shareholder with more than $10 \%$ voting rights, but that there are one or more other shareholders (usually banks or the State) with similarly large holdings. We conclude that such corporations may be thought of as controlled by a coalition more than by the family. In order to obtain a clearer response to the question whether family control is negative, indifferent or positive for European corporation, we resort to the strict definition of family control we have just described, in which the controlling power of the family through the voting rights held cannot be denied. This leads to the count of 314 family-controlled corporations we find in panels B and C, instead of the 355 reported in Panel A.

\footnotetext{
${ }^{6}$ In this group we include both widely-held corporations and corporations controlled by widely-held ones.
} 


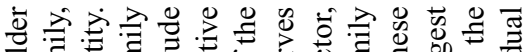

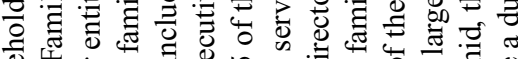

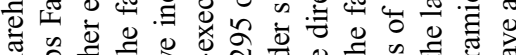

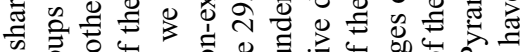

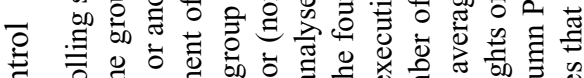

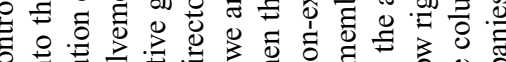

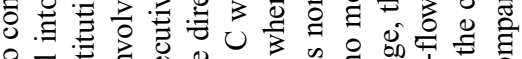

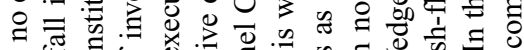

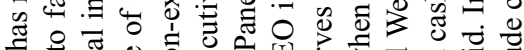
岁

प $=0$.

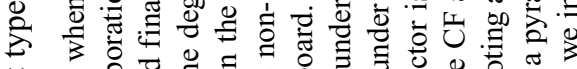

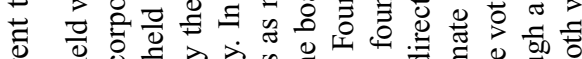

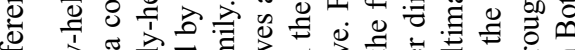

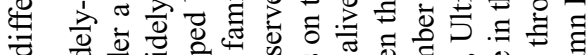

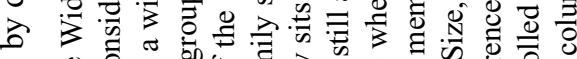

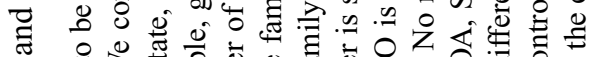

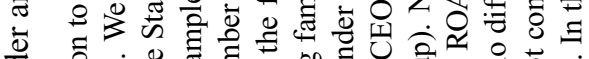

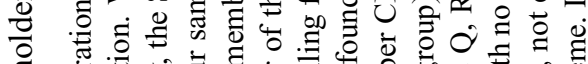

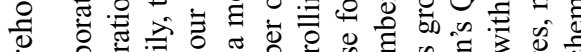

音

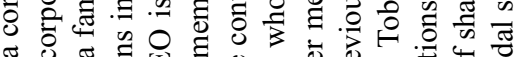

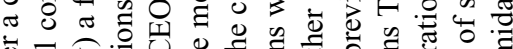

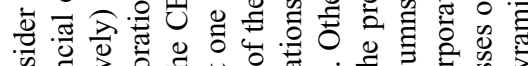

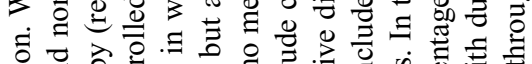

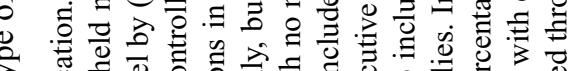

द.

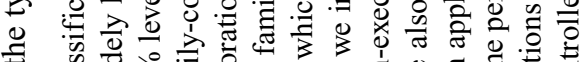

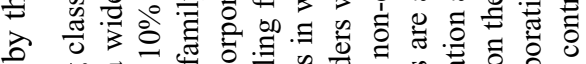

की

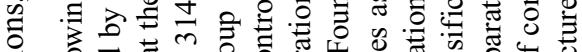

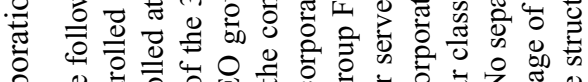

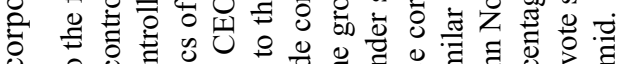

800 o c.

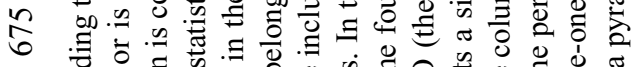

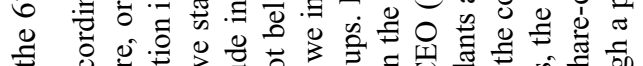

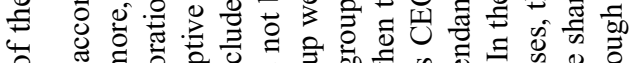

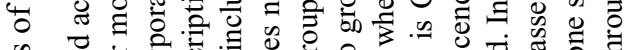

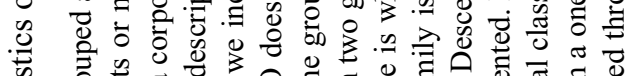

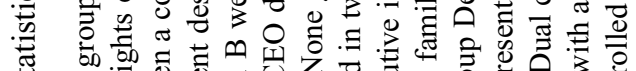

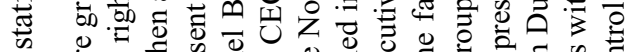

o

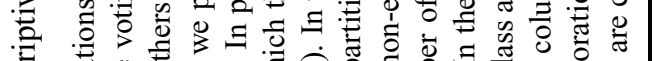

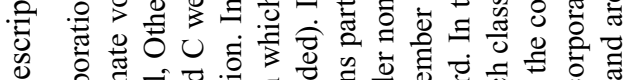

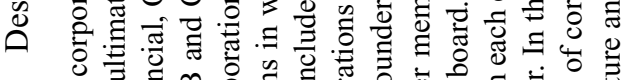

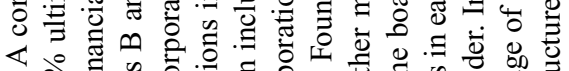

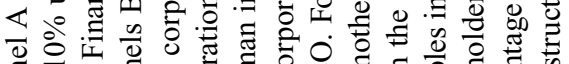

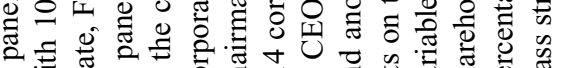

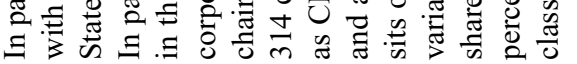

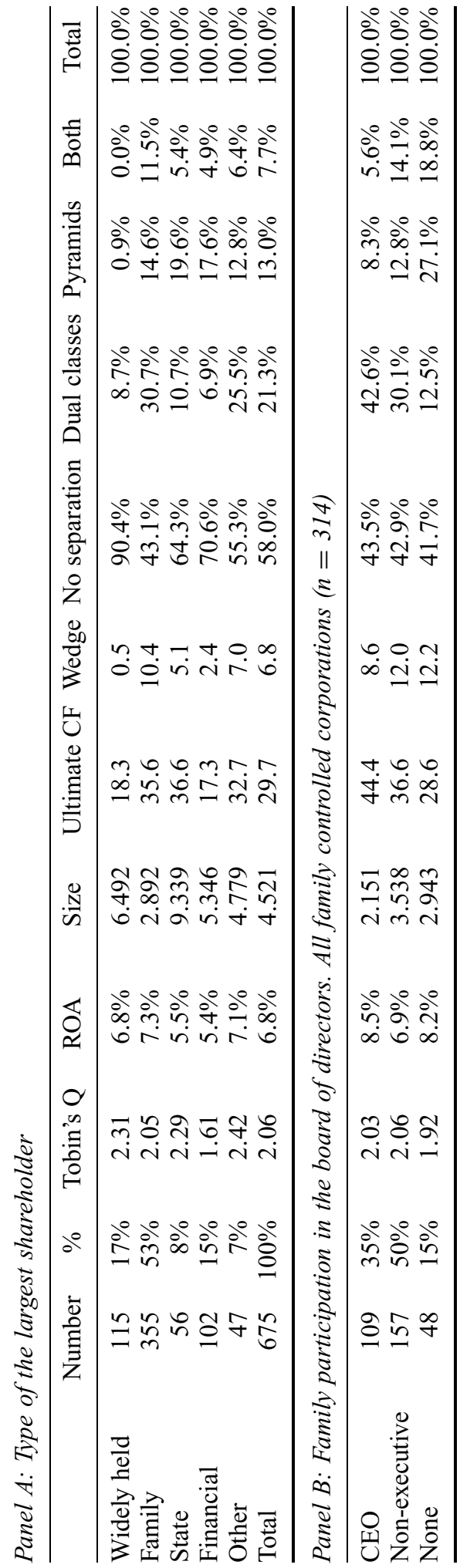




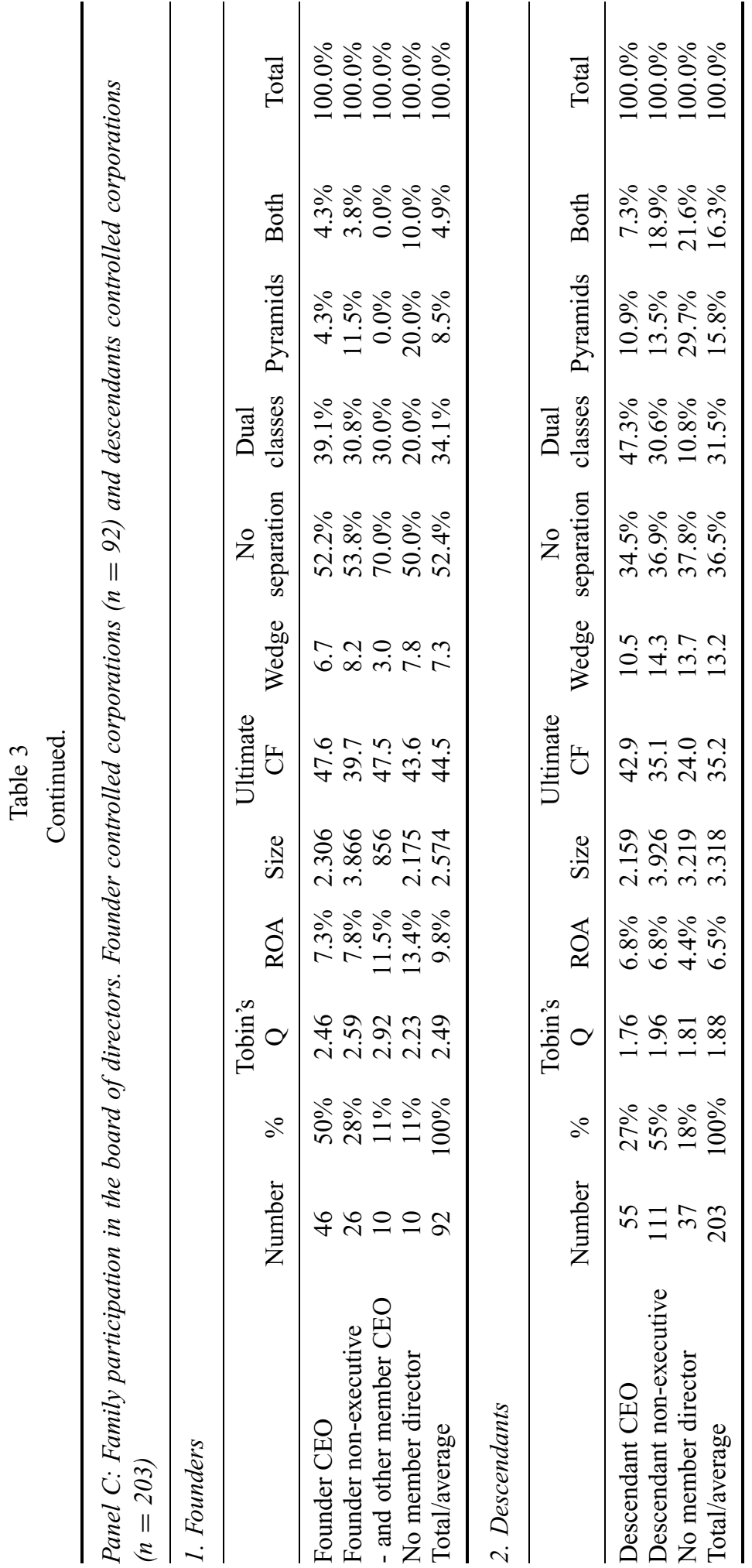


In Panel B we can observe that in nearly $35 \%$ of the 314 corporations the CEO is a member of the family; in half of them the CEO is not a member of the controlling family, but at least one member of the family sits on the board of directors; ${ }^{7}$ in just $15 \%$ the family does not sit on the board at all. Average valuation and performance measures between corporations with family CEO and family-non-executives are quite similar, but Tobin's Q is lower for corporations in which the family stays outside of the board. The average family-CEO corporation is smaller. The percentage of corporations that are controlled through control-enhancing devices is quite similar across the three types. However, the average size of the wedge between voting and cash-flow rights is smaller for family-CEO corporations.

In Panel $\mathrm{C}$ we split the sample by founder ${ }^{8}$ and descendants corporations. Foundercontrolled firms are 92 out of $295,{ }^{9}$ or about $32 \%$ of family corporations. In more than half of them the founder is also the CEO, and in about $40 \%$ the founder is a non-executive director (but then, it is not rare for the CEO to be another member of the family). In descendants-corporations the proportion between top-management and board-level family participation reverses. In little more than $25 \%$ of them the CEO is a member of the family, while one or more members of the family take a non-executive position on the board in about $55 \%$.

Founder corporations are better off in terms of average Tobin's Q and operating performance. Founder corporations also exhibit a more concentrated ownership and far less separation between voting and cash-flow rights. This can be seen both in the percentage of corporations without such separation $(52 \%$ in founder-corporations and $36 \%$ in descendants-corporations), and in the average wedge, that is clearly higher in descendants-corporations.

\section{The Effect of Family Control on Firm Value and Performance}

We can now move to the core of the paper, i.e. the analysis of the relation between market valuation (Tobin's Q) and operating performance (ROA) on one side, and the variables representing ownership concentration and family control, on the other side.

\footnotetext{
${ }^{7}$ Often being its non-executive chairman (it happens in $49.3 \%$ of the corporations in which the CEO is not from the family, but at least one non-executive is).

${ }^{8}$ We have to explain what we mean by the term 'founder'. The simplest case is the one of a corporation whose founder is still alive (and, obviously, has voting-right control, alone or together with other members of his family). However, we consider a corporation foundercontrolled also when it is controlled by another corporation that, in its turn, is controlled by its own founder. Finally, we consider founder-controlled a corporation controlled by an individual that did not found it, but took control of it without being a descendant of the previous controlling family (an illustrious example is that of Mr. Arnault, who became the controlling shareholder of the Dior-LVMH group without belonging to the founding family). We consider this individual as the founder of a new family dynasty. Consistently, we also consider descendants, the descendants of someone that took control of a corporation without being its founder.

${ }^{9}$ We refer to a total of 295 , because for two of the 314 family-controlled corporations we are missing information about the composition of the board of directors, and for a further 17 we were not able to conclude whether the corporation is still run by the founder or by his descendants.
} 
The general form for the regressions is:

$$
\begin{aligned}
& \text { Firm performance }_{i t}=\mathrm{a}+\mathrm{b}\left(\text { family }_{\text {firm }} \text { f }_{t}\right)+\mathrm{c}\left(\text { ownership }_{\text {variables }}{ }_{i t}\right) \\
& +\mathrm{d}\left(\text { control variables }_{i t}\right)+\mathrm{e}(\text { two digit SIC code dummy } \\
& \text { variables })+\mathrm{f}(\text { year dummy variable })+\mathrm{g}(\text { country dummy } \\
& \text { variables })+\varepsilon_{i t}
\end{aligned}
$$

where

Firm performance

Family firm

Ownership variables

Control variables

Two-digit SIC code dummy

Year dummy variables

Country dummy variables
Tobin's Q (natural logarithm of) and ROA;

binary variable that equals one when a corporation is controlled by a family ${ }^{10}$ and zero otherwise; in various regressions we use more binary variables identifying different types of involvement of families in management; a vector composed of the share of ultimate cash-flow rights and the difference between share of voting and share of cash-flow rights (wedge); in some regression specifications this will be omitted ${ }^{11}$;

a vector of variables composed of total assets (natural logarithm of), leverage (book value of total financial debt / book value of equity), sales growth in the previous year; dummy variables that capture industry fixed effects; dummy variables that capture year fixed effects; dummy variables that capture country fixed effects.

A problem we encounter is the presence of outliers in the dependent variables, especially in Tobin's Q. In the years 1999-2001 the stock market conditions produce a number of very high Tobin's Qs that are larger than in previous studies (for instance, the average Tobin's $Q$ is 4.22 for unregulated utility firms). Although we use the natural logarithm of Tobin's $Q$ in order to limit the impact of skewness, we note that some extreme values of $\ln (Q)$ could still affect the results in a significant way. We deal with this problem by applying a winsorising procedure that censors Tobin's Q at the 5th and 95 th percentiles by setting extreme values to the 5 th and 95 th percentile values, respectively.

In the following section we examine the general relation between corporate performance, ownership concentration and family control.

\section{A. Corporation performance and family control}

In Table 4 we report the outcome of two different regression specifications in which the independent variable of main interest is the dummy for family control.

In the first specification (columns 1 and 3), that we can define 'gross-of-thecontrolling-strategy', we do not include in the regressors the share of ultimate cash-flow rights and the difference between the share of voting and cash-flow rights. If value and operating performance are correlated both to the type of the controlling shareholder

\footnotetext{
${ }^{10} \mathrm{We}$ employ the strict definition of family control that brings to 314 family-controlled corporations, as we explain in section II.B.

${ }^{11}$ We also test, but do not report, specifications in which we control for the non-linear effects of the share of cash-flow rights of the largest shareholder. The results of these specifications do not introduce relevant changes in the relation between value and performance and family control.
} 
Table 4

The results of regressions of firm valuation and performance on ownership concentration and family control

In this table we report the results of OLS regressions, with dependent variables Tobin's Q and ROA, for the years 1999-2001. Family is a dummy variable taking value 1 for family-controlled corporations. Cash-flow rights is the share of cash-flow rights held by the largest shareholder. Wedge is the difference between the share of voting and cash-flow rights held by the largest shareholder. $\mathrm{Ln}$ (Size) is the natural logarithm of total assets. Leverage is the book value of total financial debt divided by the book value of equity. Sales growth is the growth of sales in the previous year. We include among the regressors the fixed effects for SIC two digits, years, and countries. T-statistics from heteroskedasticity consistent (Huber/White) standard errors appear in parentheses.

\begin{tabular}{lcccc}
\hline Dependent variable & \multicolumn{2}{c}{ Ln (Tobin's Q) } & \multicolumn{2}{c}{ ROA } \\
\hline Regression specification & 1 & 2 & 3 & 4 \\
Family & 0.0481 & 0.0849 & 0.0099 & 0.0113 \\
& $(2.16)$ & $(2.68)$ & $(2.66)$ & $(2.43)$ \\
Cash-flow rights & & -0.0003 & & 0.0001 \\
& & $(-0.41)$ & & $(1.21)$ \\
Wedge & & -0.0039 & & -0.0003 \\
& & $(-2.74)$ & & $(-1.47)$ \\
Ln (Size) & 0.0174 & 0.0199 & 0.0035 & 0.0042 \\
& $(1.08)$ & $(1.36)$ & $(2.39)$ & $(2.43)$ \\
Leverage & -0.0249 & -0.0271 & -0.0105 & -0.0109 \\
& $(-2.11)$ & $(-2.39)$ & $(-4.12)$ & $(-4.47)$ \\
Sales growth & 0.1729 & 0.1698 & 0.0180 & 0.0178 \\
& $(4.37)$ & $(4.22)$ & $(2.16)$ & $(2.14)$ \\
R-squared adj. & $32.46 \%$ & $33.09 \%$ & $20.03 \%$ & $20.40 \%$ \\
N. Observations & 1852 & 1852 & 1852 & 1852 \\
\hline
\end{tabular}

(family or not) and to the ownership structure chosen by the controlling shareholder (share of cash-flow rights and separation between cash-flow and voting rights), then the coefficient on the dummy variable, in this specification, captures both the 'pure' effect of the type of controlling shareholder and the effect of the average ownership structure chosen by that type.

In the second specification (columns 2 and 4), that we can define 'net-of-thecontrolling-strategy', we include the dummy-variable for family along with the two continuous variables representing the share of cash-flow rights and the wedge between the voting and the cash-flow rights held by the largest shareholder. In this second specification we can interpret the coefficient of the dummy as informative of the 'pure' effect of the type of control, i.e. the specific skills or disadvantages that could make families different as controlling shareholders, separated from the effect of the ownership structure (that is simultaneously estimated by assuming it is equal for family and nonfamily firms).

The results in Table 4 show that in continental Europe family control goes together with higher value and operating performance. In all the regressions, either with dependent variable Q (regressions 1 and 2) or with dependent variable ROA (regressions 3 and 4 ), the coefficient on the dummy-variable 'family' is positive and highly statistically significant). This result suggests that family control is beneficial both when we measure a 
'pure family effect' separated from an 'ownership structure effect' and when we measure an 'overall family effect'.

More in detail, in regressions 2 and 4 (net-of-the-controlling-strategy) the coefficients on the family-dummies are positive and statistically significant both when the dependent variable is Q (regression 2, statistical significance 1\%) and when it is ROA (regression 4, statistical significance 5\%). This means that, for any given combination of cashflow rights and wedge, family corporations tend to exhibit clearly better valuation and operating performance than non-family firms.

However, although it cannot be said that separation of voting and cash-flow rights is a necessary corollary of family control (in $43.1 \%$ of family-controlled corporations the family holds an identical share of voting and cash-flow rights), family corporations do resort more often to control-enhancing devices, and this makes their ownership structure less efficient in terms of valuation and operating performance, as is shown by the negative signs on the Wedge variable in regressions 2 and 4. Therefore, when we measure the joint effect of family control and ownership structure, as we do in regressions 1 and 3 , the effect of family control actually turns out to be still positive, but smaller. Even in this 'gross-of-the-controlling-strategy' specification, however, the positive family effect is present and highly statistically significant (5\% level for Q and $1 \%$ for ROA).

We have finally to mention that we run a regression specification (not reported in the tables) in which we also include as independent variables the interaction terms family*cash-flow rights, and family*wedge. The estimates for the interaction terms are not significant when we employ ROA as the dependent variable. On the contrary, they are significant when we employ Tobin's Q, since the value of the family-dummy becomes higher, and the regression line for both cash-flow rights and wedge is more steeply downward sloping in the case of family-controlled corporations. On one side, this suggests that the market is more diffident towards management-entrenching strategies when they are put in place by family firms (a similar result is documented for Swedish firms by Cronqvist and Nilsson, 2003). On the other side, this reinforces the evidence of the positive properties of family control once we separate it from the effect of the quantitative ownership variables.

A last remark about the results in Table 4 concerns the estimates for the cash-flow and wedge variables. The general opinion of the relationship between value/performance and these variables, based on papers by Claessens et al. (2002), Lins (2003) and Gompers et al. (2004) - that regard respectively East Asia, various emerging markets, and the USA - is that (i) valuation and performance increase in the cash-flow rights of the largest ultimate shareholder and (ii) valuation and performance decrease in the wedge between the voting and the cash-flow rights of the largest shareholder. However, we find practically no association with cash-flow rights as far as Q is concerned, and only weak evidence for ROA (the positive coefficients on ROA are not statistically significant). Results are more aligned with expectations for what regards the wedge variable, since there is clear evidence of negative association with $\mathrm{Q}$, and weak evidence of negative association with ROA (the estimated coefficients are actually negative, though not statistically significant). The reasons for the departure from the results found in other economies about the relationship between value/performance and cash-flow rights ${ }^{12}$ cannot be investigated in this paper, but may be an interesting topic for further research.

\footnotetext{
${ }^{12}$ A similar result is however found by Lins (2003) in a sample of 1433 firms from 18 emerging markets.
} 


\section{B. The relation between firm performance and family involvement}

Family control in general seems to have a positive effect, but what about different types of family control? There is evidence, mainly from the USA, that the performance of corporations run by their founders is actually above the average (McConnaughy et al., 1998; Palia and Ravid, 2002; Anderson and Reeb, 2003; Adams et al., 2004; Fahlenbrach, 2005), but the same cannot be said when descendants take the reins (McConnaughy et al., 1998; Pérez-González, 2006; Villalonga and Amit, 2006). Furthermore, it is possible to argue that outside managers can take into the corporation skills and experiences that not only descendants, but sometimes also founders, may not

Table 5

The relationship between firm value and performance, and family involvement in management

In this table we report results of OLS regressions of Tobin's Q and ROA on proxy variables for the involvement of the family in managing the corporations. In regressions in columns 1 and 3 , we include among regressors Cash-flow rights (share of cash-flow rights held by the largest shareholder) and Wedge (difference between the share of voting and cash-flow rights held by the largest shareholder. In panel A Family CEO takes value 1 for corporations in which the CEO is a member of the controlling family. Family non-executive takes value 1 for corporations where the CEO is not a member of the family, but at least one member sits on the board as non-executive director. Family not on the board takes value 1 when no member of the family sits on the board. In panel B Founder takes value 1 when the founder is still alive, Descendants takes value 1 in all other family-controlled corporations. In all regressions we include as control variables (but do not report the results in the table): $\mathrm{Ln}$ (Size) (natural logarithm of total assets), Leverage (book value of total financial debt divided by the book value of equity), and Sales growth (growth of sales in the previous year). We then include the fixed effects for SIC two-digits, years and country. T-statistics from heteroskedasticity consistent (Huber/White) standard errors are in parentheses.

Panel A: Family CEO vs. family non-executive

\begin{tabular}{lcccc}
\hline Dependent variable & \multicolumn{2}{c}{ Ln (Tobin's Q) } & \multicolumn{2}{c}{ ROA } \\
\hline Family CEO & 0.0806 & 0.0532 & 0.0095 & 0.0091 \\
Family non-executive & $(1.72)$ & $(1.34)$ & $(1.59)$ & $(1.78)$ \\
& 0.1007 & 0.0603 & 0.0172 & 0.0154 \\
Family not on the board & $(2.78)$ & $(2.29)$ & $(3.41)$ & $(3.95)$ \\
& 0.0416 & 0.0026 & -0.0051 & -0.0075 \\
Cash-flow rights & $(0.89)$ & $(0.07)$ & $(-0.63)$ & $(-1.05)$ \\
Wedge & -0.0004 & & 0.0001 & \\
& $(-0.48)$ & & $(1.05)$ & \\
Ln (Size) & -0.0039 & & -0.0003 & \\
& $(-2.53)$ & 0.0182 & 0.0043 & 0.0038 \\
Leverage & 0.0202 & $(1.12)$ & $(2.48)$ & $(2.47)$ \\
& $(1.36)$ & -0.0257 & -0.0111 & -0.0107 \\
Sales growth & -0.0276 & $(-2.23)$ & $(-4.35)$ & $(-4.04)$ \\
& $(-2.46)$ & 0.1708 & 0.0173 & 0.0174 \\
R-squared adj & 0.1683 & $(4.30)$ & $(2.11)$ & $(2.13)$ \\
N. Observations & $(4.21)$ & $32.54 \%$ & $20.96 \%$ & $20.63 \%$ \\
\hline
\end{tabular}


Table 5

Continued.

\begin{tabular}{lcccc}
\hline \multirow{2}{*}{ Panel B: Founder vs. descendants } & \multicolumn{2}{c}{ ROA } \\
\hline Dependent variable & \multicolumn{2}{c}{ Ln (Tobin's Q) } & 0.0194 & 0.0192 \\
\hline Founder & 0.1405 & 0.1164 & $(5.13)$ & $(4.54)$ \\
& $(4.33)$ & $(4.02)$ & 0.0104 & 0.0082 \\
Descendants & 0.0657 & 0.0239 & $(1.55)$ & $(1.49)$ \\
& $(1.55)$ & $(0.75)$ & 0.0001 & \\
Cash-flow rights & -0.0004 & & $(0.91)$ & \\
& $(-0.52)$ & & -0.0003 & \\
Wedge & -0.0037 & & $(-1.41)$ & 0.0038 \\
& $(-2.33)$ & 0.0197 & 0.0043 & $(2.29)$ \\
Ln (Size) & 0.0211 & $(1.26)$ & $(2.31)$ & -0.0109 \\
& $(1.48)$ & -0.0277 & -0.0112 & $(-4.28)$ \\
Leverage & -0.0290 & $(-2.29)$ & $(-4.52)$ & 0.0177 \\
& $(-2.47)$ & 0.1689 & 0.0176 & $(2.18)$ \\
Sales growth & 0.1672 & $(4.26)$ & $(2.16)$ & $20.43 \%$ \\
& $(4.14)$ & $32.84 \%$ & $20.74 \%$ & 1852 \\
R-squared adj. & $33.34 \%$ & 1852 & 1852 & \\
N. Observations & 1852 & & & \\
\hline
\end{tabular}

have. In this case, the mere fact that the CEO is a member of the family should have a negative effect on performance. Therefore, in the present section we turn to analyse different cases of family control.

In Tables 5 and 6 we report results of regressions in which we include dummyvariables representing the different types of family involvement. The regressions are run on the whole sample, therefore the coefficients on dummy-variables inform us if corporations characterised by a given type of family participation are different in their average valuation and operating performance from non-family firms.

We seek evidence on the following points. First, we wish to understand the effect of family control when a member of the controlling family is CEO of the company. Second, we look at possible differences between family firms controlled by founders and by descendants, following the mainly US evidence about superior performance of founders. Third, we are particularly interested in the performance of family firms whose CEO is a descendant, a case that is often seen as a negative outcome of family control, since it is a priori likely that the descendants do not share the founder's distinctive entrepreneurial skills.

C.1 Family CEO vs. Family non-executive-directors. In Panel A of Table 5 we abstract from the founder-descendants alternative, and simply analyse different degrees of involvement of the family, by considering a first dummy-variable that takes the value one when the CEO belongs to the family, a second dummy-variable that takes the value one when the CEO is not a member of the family but at least one member of the family sits on the board of directors, and a third dummy-variable for the case of no family present on the board at all. The picture released by these regressions is clear; the general positive effect of family control we already noticed can be split according to the degree of involvement of families in management. The effect is confirmed to be clearly positive 
Table 6

The relationship between firm value and performance, and the involvement in management of founders and descendendants

In this table we report results of OLS regressions of Tobin's Q and ROA on proxy variables for the involvement of founders and descendants in managing the corporations. In regressions in columns 1 and 3, we include among regressors Cash-flow rights (share of cash-flow rights held by the largest shareholder) and Wedge (difference between the share of voting and cash-flow rights held by the largest shareholder). Founder CEO represents when the founder is CEO, Founder non-executive when the founder sits on the board as non-executive director, Founder not on the board when the founder is still alive but no member of the family sits on the board. Descendants CEO, Descendant non-executive, Descendant not on the board represent the equivalent situations for family controlled corporations in which the founder passed away. In all regressions we include as control variables (but do not report the results in the table): $\mathrm{Ln}$ (Size) (natural logarithm of total assets), Leverage (book value of total financial debt divided by the book value of equity), and Sales growth (growth of sales in the previous year). We then include the fixed effects for SIC two-digits, years and country. T-statistics from heteroskedasticity consistent (Huber/White) standard errors appear in parentheses.

\begin{tabular}{lcccc}
\hline Dependent variable & \multicolumn{2}{c}{ Ln (Tobin's Q) } & \multicolumn{2}{c}{ ROA } \\
\hline Founder CEO & 0.1338 & 0.1184 & 0.0137 & 0.0140 \\
& $(3.67)$ & $(2.79)$ & $(2.52)$ & $(2.14)$ \\
Founder non-executive & 0.1813 & 0.1597 & 0.0255 & 0.0250 \\
Founder not on the board & $(3.27)$ & $(2.92)$ & $(4.84)$ & $(4.38)$ \\
& -0.0197 & -0.0569 & 0.0150 & 0.0129 \\
Descendant CEO & $(-0.23)$ & $(-0.87)$ & $(0.89)$ & $(0.91)$ \\
& 0.0453 & 0.0143 & 0.0110 & 0.0097 \\
Descendant non-executive & $(0.59)$ & $(0.22)$ & $(1.19)$ & $(1.21)$ \\
& 0.0808 & 0.0392 & 0.0149 & 0.0122 \\
Descendants not on the board & $(2.22)$ & $(1.39)$ & $(2.31)$ & $(2.43)$ \\
& 0.0285 & -0.0089 & -0.0033 & -0.0063 \\
Cash-flow rights & $(0.56)$ & $(-0.18)$ & $(-0.35)$ & $(-0.73)$ \\
& -0.0003 & & 0.0001 & \\
Wedge & $(-0.45)$ & & $(0.74)$ & \\
Ln (Size) & -0.0035 & & -0.0003 & \\
Leverage & $(-2.16)$ & & $(-1.27)$ & 0.0039 \\
Sales growth & 0.0208 & 0.0196 & 0.0043 & $(2.46)$ \\
& $(1.40)$ & $(1.21)$ & $(2.40)$ & -0.0111 \\
R-squared adj & -0.0299 & -0.0288 & -0.0114 & $(-4.25)$ \\
N. Observations & $(-2.63)$ & $(-2.48)$ & $(-4.44)$ & 0.0177 \\
& 0.1640 & 0.1648 & 0.0177 & $(2.23)$ \\
& $(4.00)$ & $(4.08)$ & $(2.22)$ & $20.72 \%$ \\
& $33.57 \%$ & $33.10 \%$ & $21.02 \%$ & 1852 \\
\hline
\end{tabular}

when the family takes up the role of monitoring by assuming non-executive positions on the board of directors, since the dummies for the presence on the board of non-executive family members is positive and highly statistically significant (in Q regressions, once at the $5 \%$ and the other at the $1 \%$ level; in ROA regressions, always at the $1 \%$ level). On the other hand, when a family member takes the position of CEO, the evidence of the better position of family vs. non family-firms becomes weaker. Notice that the size of the estimates for the family-CEO dummies does not decline abruptly with respect to the size 
of the family-non-executive dummies. Rather what declines is statistical significance both for $\mathrm{Q}$ and ROA, the coefficient remains significant at the $10 \%$ level in one of the two regressions - suggesting that there is a much larger variance in the market valuation and operating performance of companies run by family-CEOs, coupled with slightly lower average values, compared to companies that are simply monitored by families. But this does not mean that family-CEO firms are worse off than non-family firms, since the regression in the first column of Panel A Table 5 shows that Q is $8.4 \%$ higher in family-CEO firms, and the one in the third column shows that the coefficient on the family-CEO dummy is equal to $14 \%$ of the overall mean ROA.

Finally, note that the results of Panel A Table 5 do not suggest that family firms perform better the less the family takes interest in the company. It is true that it seems better when the family does not manage and limits itself to monitoring; but the group of worst-performing family firms are those in which the family does not manage and stays outside of the board. For this group there is no sign of better performance with respect to non-family firms, and there could even be worse performance, as is suggested by the (not statistically significant) negative sign of the coefficients when ROA is the dependent variable. This is consistent with the idea that family control is beneficial for the firm when coupled with some degree of involvement of the family. ${ }^{13}$

C.2. Founders vs. descendants. In Panel B of Table 5, we consider a different grouping criterion of family firms, that distinguishes them into two types, those controlled by the founder and those controlled by descendants. The criterion states simply that, if the founder is still alive - no matter her role in the firm, if any - the family-controlled firm is considered a founder-firm, otherwise it is considered a descendant-firm.

The results are clear and statistically strong, showing that family firms perform much better when they are still controlled by their founders. The size of the difference in founder-firm average valuation and operating performance with respect to both descendant-controlled and non-family corporations is impressive. If we compare the size of the point-estimates, we note that founder-controlled corporations' average Tobin's Q is $12.3 \%$ higher than in non-family firms, and their ROA is $28.2 \%$ higher than the overall mean (gross-of-the-controlling-strategy specification).

Although a similarly large overperformance of founder-led corporations is found in the USA too (see Adams et al., 2004), we consider the hypothesis that this strong result is due to the omission of control variables representing age since foundation or since IPO. When we run regressions on the sub-samples formed by the corporations for which these data are available, including age-foundation and/or age-IPO as control variables, the results for the founder dummy-variable are nearly unchanged. We interpret this as evidence that the founder effect is distinct from a young-firm effect. ${ }^{14}$

\footnotetext{
${ }^{13}$ We also test whether the coefficients of the three dummy variables are statistically different one from the other. This is true when we compare the dummies for family-CEO and familynon-executive with the dummy for family-not-on-the board, in regressions in which ROA is the dependent variable.

${ }^{14}$ Only $20 \%$ of the 264 family corporations whose IPO took place after 1988 , and $30 \%$ of the 65 corporations founded after 1978, are still run by their founder. Therefore, we can effectively measure the distinct effects of the age and of the presence of the founder. The coefficient on the age variable is always positive, that means that younger corporations, in term of foundation date or IPO date, do actually perform better. However, the size and the statistical significance of the founder dummy-variable are nearly unchanged.
} 
It is thus clear that founder-corporations perform significantly better than descendants-corporations. ${ }^{15}$ However, descendants-corporations are no worse than nonfamily firms, as the positive sign of coefficients on the dummy-variable descendants show. Tobin's Q is $6.6 \%$ higher than in non-family firms in the net specification, and $2.4 \%$ in the gross one; ROA is higher than the overall mean by, respectively, $15.3 \%$ and $12.0 \%$. But, although sizeable - especially in the case of ROA - these point-estimates are never accompanied by statistical significance, so that we cannot reliably say that descendant-firms are better than non-family ones.

C.3. Founders and descendants, and their involvement in the family company. Previous research has highlighted negative performance of family firms where a descendant assumes the role of CEO. This result has intuitive appeal. While exchange listed companies that have been brought to market by founders are likely to have been run by skilled entrepreneurs, there is no reason to suppose that heirs inherit the managerial skills of founders. Thus, the decision to keep the CEO position in the family can simply mean that a selection of the best candidates for the position has not been put in place, in view of the advantages of enjoying the private benefits of this position in the family.

In Table 6, therefore, we present a finer partition of the family involvement in management, by considering both the founder/descendants alternative and the different roles on the board. Thus, we include in the regression six dummy-variables representing different groups of family-firms:

1 Founder $\mathrm{CEO}=$ family-controlled firm in which the founder is CEO (often also chairman);

2 Founder non-executive $=$ family-controlled firm in which the founder sits on the board as non-executive (often is non-executive chairman);

3 Founder not on the board = family-controlled firm in which the founder is still alive but neither the founder nor any other family member sits on the board;

4 Descendant $\mathrm{CEO}=$ family-controlled firm, family in the second or later generation, CEO belonging to the family;

5 Descendant non-executive = family-controlled firm, family in the second or later generation, member of the family on the board as non-executive;

6 Descendant not on the board = family-controlled firm, family in the second or later generation, no member of the family on the board.

The neatest result in Table 6 is that the statistically significant positive difference between founder-firms and non-family firms - that we already noticed while commenting on Table 5 - holds both when the founder is CEO and when she is non-executive. However, it is noticeable that both founder and descendant firms seem to be better off when the CEO is from outside the family. While the result for descendants could be expected, it was not a foregone conclusion that founder-firms, that on average are already more profitable than the others, perform even better when not all managerial power is kept within the family.

As far as the comparison between descendant-firms and non-family firms is concerned, results in Table 6 trace a more interesting picture than in Table 5, where we could notice no statistical difference between the two groups. The interesting evidence

${ }^{15}$ The dummy for founder is statistically different from the dummy for descendants in regressions in which Tobin's $Q$ is the dependent variable. 
arises from the separation between descendant-CEO and descendant-non-executive firms. There is rather strong statistical evidence that descendant-non-executive firms perform better than non-family firms. ${ }^{16}$ Descendant-CEO firms, on the contrary, are not statistically different from non-family firms. However, there is no suggestion, contrary to what is found in non-European papers, that descendant-CEO firms are inferior to non-family firms in terms of market valuation or operating performance, as is shown by the fact that the estimates of the descendant-CEO dummies are always positive, albeit not statistically significant. The only negative signs appear for the dummy-variables of family not in the board, confirming that the absence of the family from both management and monitoring is really the most critical case for family control.

Coming back to the better performance of all family-firms when the CEO is an outsider, a more detailed look reveals that the estimates concerning market valuation (Tobin's Q) for founder-CEO and founder-non-executive are rather close, and both of them quite large compared to the estimates for descendant-CEO and descendant-nonexecutive. When we consider instead operating performance (ROA), we notice that the estimate for the founder-non-executive dummy takes a clearly larger value, and that the value taken by the founder-CEO dummy is even slightly lower - at least in the net regression (third column) - than that of the descendant-non-executive. In some sense, the market valuation of family firms seems to be affected by more confidence on the value added by a founder-CEO than what would be justified on the basis of operating performance.

A similar but opposite observation can be made when we consider the difference between descendant-CEO and descendant-non-executive firms. In this instance, we find that the difference in market valuation in favour of descendant-non-executive is larger than what seems implied by the difference in operating performance, so that the market seems suspicious of a descendant-CEO beyond what should be the case on the basis of accounting profits.

\section{Further Analysis and Discussion of the Statistical Evidence}

\section{A. Sample selection effects}

We consider the possibility that some results are driven by the sample selection criteria we adopt, that were explained in Section 2. Along with common criteria (we exclude financial firms and regulated utilities), we require for inclusion total assets (accounting value of equity plus net financial debt) larger than $€ 300$ million in 1999. We check therefore for the possibility that the latter criterion makes us pick successful companies that recently showed more than average growth, thereby artificially selecting observations with higher Tobin's Q and ROA, that could lead to an unknown bias in the comparison between family and non-family firms, and across different types of family companies.

\footnotetext{
${ }^{16}$ In ROA regressions the dummy for this case is positive and statistically significant far beyond the 5\% threshold, while the dummy for the descendant-CEO case takes a smaller value and is not statistically significant. The dummy for descendant-non-executive is also positive and statistically significant in the net specification of the regression when Q is the dependent variable; it is not in the gross specification, due to the important value-discount arising from the diffuse presence of control-enhancing devices in descendant-firms (that was clearly visible in Panel $\mathrm{C}$ of Table 3 ).
} 


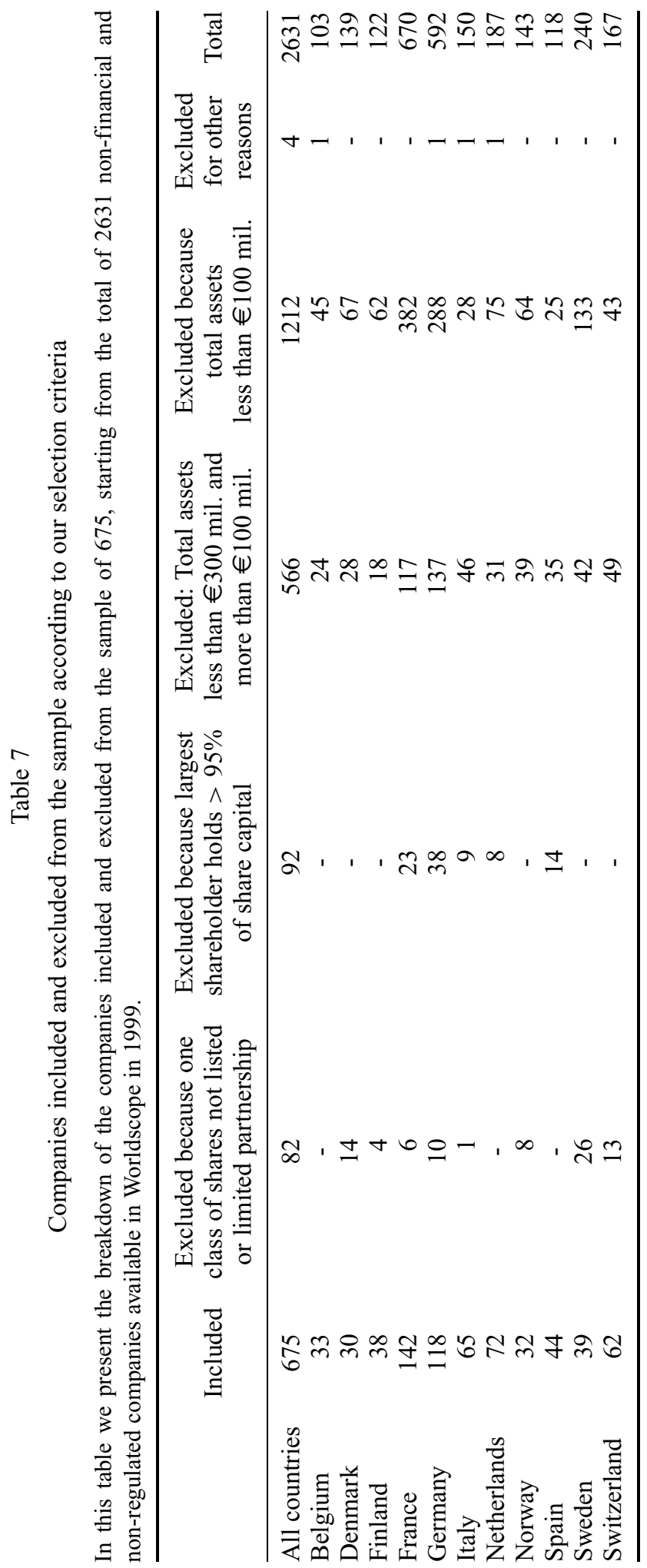


Table 8

Average ROA and Tobin's Q for different size classes

In this table we present the mean and the median ROA and Tobin's Q for continental European nonfinancial and non-regulated corporations in the Worldscope database in 1999. Corporations are divided into three classes. In the first we include corporations with a book value of balance sheet Total assets larger than $€ 300$ million. This size class corresponds to the size class of companies examined in the paper. The other two classes correspond to smaller corporations, that are excluded from the sample we study.

\begin{tabular}{lcccccccc}
\hline & & & \multicolumn{2}{c}{ Tobin's Q } & & \multicolumn{2}{c}{ ROA } \\
Sample & Number & $\%$ & & Mean & Median & & Mean & Median \\
\hline Total assets value $<100$ & 1212 & 46 & 2.69 & 1.73 & & $4.82 \%$ & $6.06 \%$ \\
Total assets value $(100-300)$ & 566 & 22 & & 2.05 & 1.42 & & $7.42 \%$ & $7.24 \%$ \\
Total assets value $>300$ & 853 & 32 & & 1.99 & 1.38 & & $6.22 \%$ & $5.99 \%$ \\
\hline
\end{tabular}

To consider it, we observe that in Worldscope, for the 11 countries, the total number of non-financial and non-regulated corporations with accounting and market price data is 2,631 in the base year 1999. In Table 7 we report their distribution across countries, distinguishing the number of companies with (a) asset size more than $€ 300$ million, (b) asset size between $€ 100$ and 300 million, (c) asset size less than $€ 100$ million. The pool from which we draw ${ }^{17}$ comprises one third of the total number of firms. The largest group is the one with the smallest firms ( $46 \%$ of the total), while the mid-sized firms amount to less than one quarter of the total.

We then consider the measure of Tobin's Q and ROA for all the 2,631 companies, and obtain the results that are summarised in Table 8 . It is easy to notice that, on average, firms with total assets below $\$ 300$ million that are excluded from our sample, exhibit higher valuation, and, except in the case of the smallest companies, higher profitability than firms that are included. This suggests that our selection criteria did not produce a bias towards inclusion of more successful companies.

\section{B. Pooled (average) regressions}

To check the robustness of the results presented in the previous sections, we run pooled (average) regressions (Table 9) in order to minimise, when performing nonOLS regressions, the problem of correlation across residuals that is solved in OLS through the Hubert-White standard error estimation procedure. In Table 9 we report the results of: (i) random-effect regressions in which we introduce a country random-effect in place of country fixed-effects; (ii) robust regressions, in which a robust weighting function substitutes the winsorisation procedure employed in OLS regressions (and in random-effect pooled regressions too). ${ }^{18}$

\footnotetext{
${ }^{17}$ In that we arrive at 675 out of 853 companies larger than $€ 300$ million after dropping, as we explained in Section 2.A, limited partnerships, dual class corporations in which only one class is publicly traded, and companies in which more than $95 \%$ of the share capital is held by the largest shareholder.

${ }_{18}$ We use the robust regression Biweight estimator, that belongs to the class of estimators known as M-estimators of location, and works by minimising a function of the deviations of 


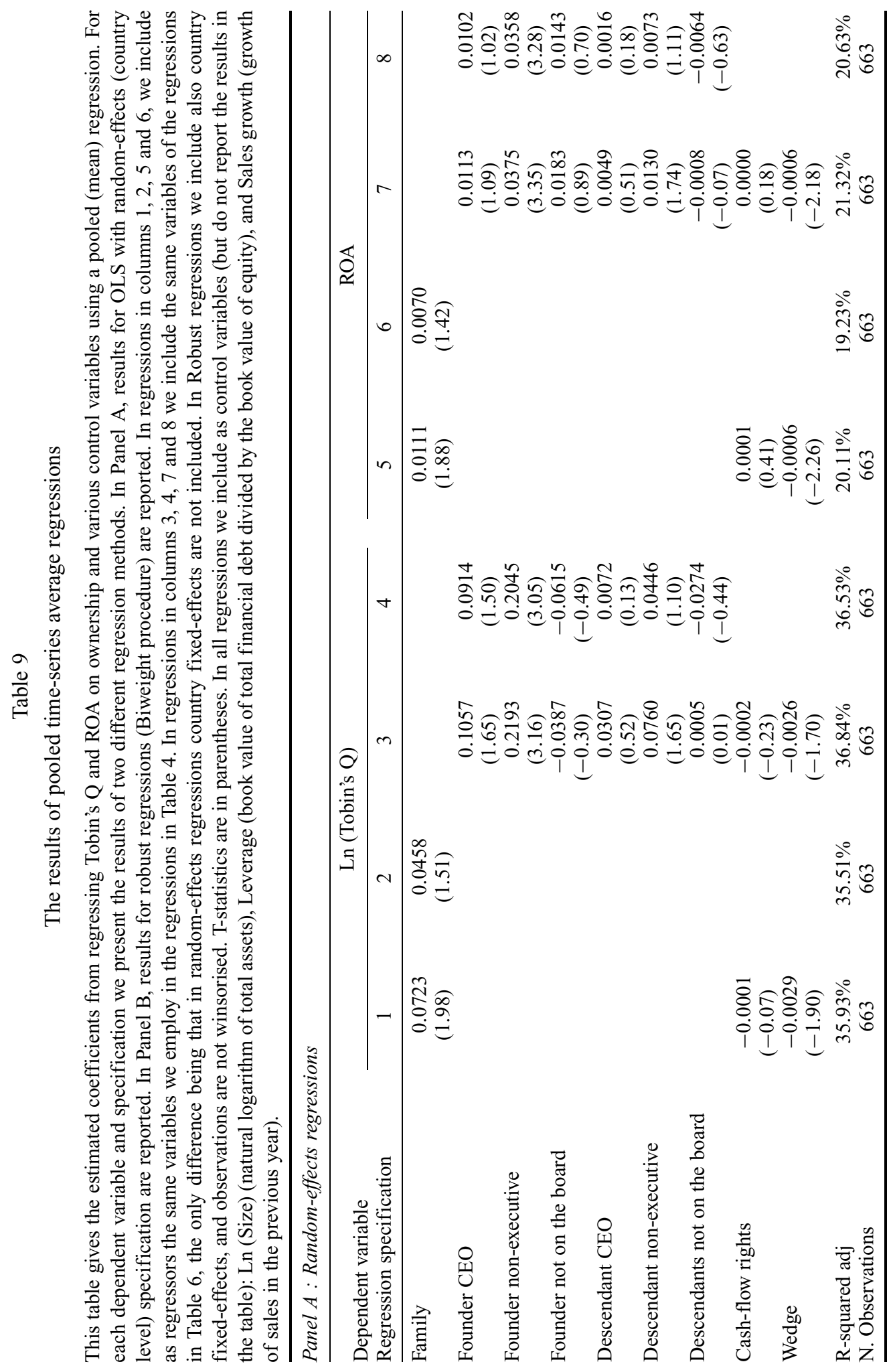




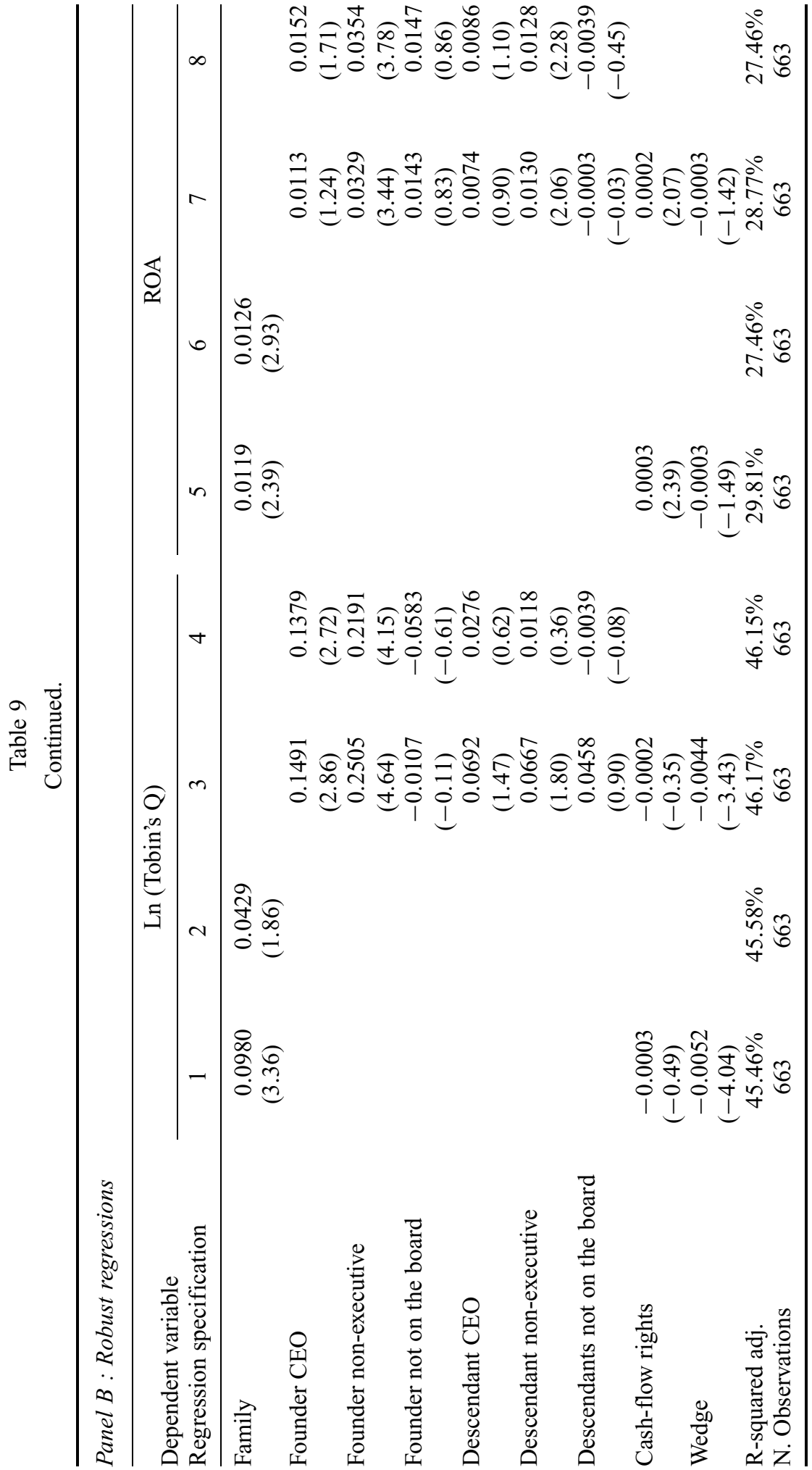


Overall, the results of pooled regressions confirm the picture suggested by OLS regressions. Results are very similar for what concerns robust regressions (Panel B), both in terms of the estimated value of coefficients and of statistical significance. They are also similar in random-effect regressions, though statistical significance is lower. In gross specifications of random-effect regressions (Panel A, columns 2, 4, 6, 8) the signs of coefficients are fully consistent with the results of OLS and robust regressions while statistical significance is reached only for the founder-non-executive dummy, but in the net specifications (Panel B, columns 1,3,5,7) we obtain both the same signs and the achievement of statistical significance as in alternative regression techniques. In conclusion, the results of pooled regressions support the evidence presented in the previous sections.

\section{On the endogeneity of ownership variables and firm performance}

Possible endogeneity problems in the regressions results have to be considered. In its simplest form, a problem of endogeneity might arise if firm performance caused choices about the share of cash-flow rights held by the largest shareholder. This could happen if under- or over-valuation prompted adjustments in the stakes of controlling shareholders, who could take advantage of private information about the true value of corporations. There could be however other more elaborate reasons for endogeneity. Demsetz and Lehn (1985) and Himmelberg et al. (1999) argue that both firm performance and managerial ownership may be endogenously determined by unobserved characteristics in the firm's contracting environment. Endogeneity arguments could also apply to the relation between performance and family control (Anderson and Reeb, 2003; Heiss and Köke, 2004), and to the relation between performance and CEO-founder persistence (Adams et al., 2004).

Therefore, we test the robustness of our results by employing linear instrumental variable regressions, in which the ownership variables representing the cash-flow rights of the first shareholder, the wedge between its voting and cash-flow rights, and the occurrence of family control, are estimated using instrumental variables. As instrumental

each observation from the estimate of location (Huber, 1981). Least squares estimates are very sensitive to contaminated observations and sometimes outliers cannot be detected by looking at residuals, since they affect the estimator in such a way that outlier diagnostics are no longer able to discover them. M-estimators may be used to address this inconvenience, though these estimators are not robust with respect to leverage points (i.e. outliers in the space of the covariates). We used this procedure because in our dataset the main source of bias comes from contamination in the error term (vertical outliers) and not in the explanatory variables (leverage points).

The procedure used consist of the following steps:

1. Estimate the residuals from OLS regression;

2. Identify deviant cases by comparing residuals with the MAD (Median Absolute Deviation) estimates, and find the weights according to Hubert or Biweight methodologies;

3. Perform a robust regression using weighted least squares;

4. Estimate the residuals from WLS and continue iteratively with step 2), until weights converge (usually within 10 iterations).

The Biweight procedure downweighs outlying data points more than the Huber methodology. Results from this last weighing function, not presented in the paper, are however similar to the Biweight estimates. 
variables we employ the alpha of the ordinary share, its volatility, ${ }^{19}$ and the age of the corporation (log of). To avoid the potential problem of 'weak instruments' (Stock et al., 2002) due to the modest correlation between the endogenous variables and our instruments, we employ LIML estimates (Anderson et al., 1982) instead of traditional 2SLS methods.

The results in Table 10 show that after controlling for endogeneity Tobin's Q is still negatively correlated with the wedge between voting and cash-flow rights and positively correlated with family control. Moreover, the positive effect of the presence of the founder - both as CEO and as non-executive - is still highly significant, and the effect of 'descendant-non-executive' is also positive and significant (10\% level).

When the dependent variable is ROA, the results are qualitatively similar to those of simple regression analysis, but are generally lacking in statistical significance, since only the presence of descendants as non-executives seems to exert a clear positive effect on performance.

The final conclusion about the endogeneity issue is thus clouded by the results of regressions of operating performance. Overall, however, we think there are no clear suggestions that the evidence provided by the OLS results is driven by endogeneity in the variables we employ.

\section{Results by country}

Obviously it is interesting to see how much the effect of family control, that up to now we considered for the continental European area as a whole, holds at the single-country level. To do this, we run regressions on the sample of 675 firms similar to those in Tables 4, 5 and 6, except that we substitute to each family-dummy of interest a set of family-dummy variables, one for each country, while maintaining the regressions identical for all the rest. Some results are summarised in Table 11, where we report the sign of coefficients of these 'family* country' dummy variables for two selected regressions. The signs we report, together with their statistical significance, immediately tell us whether in the single country the family-effect of interest is positive or not. ${ }^{20}$

In Table 11, countries are ordered according to the origin of their legal system, so we present first the five 'French-origin' countries (Belgium, France, Italy, the Netherlands, and Spain), then the two 'German-origin' (Germany and Switzerland), and finally the four 'Scandinavian-origin' (Denmark, Finland, Norway and Sweden). This allows us to highlight the fact that, if we look at the percentage of family firms in which the CEO position is held by a member of the family, we can see (line added at the bottom of Panel A) a tendency to find more family-CEOs in (legal) French-origin countries than in German-origin and, to a clearer extent, in Scandinavian-origin ones. We notice, in

\footnotetext{
${ }^{19}$ Volatility is the stock return variance, estimated over 40 months prior to each year-end; alpha is estimated by regressing 40 months of returns in excess on treasury bills on the excess returns of an index representative of the country stock market.

${ }^{20} \mathrm{We}$ also run separate regressions by country, that yield similar results. However, the regressions we comment upon exploit more efficiently the information embedded in the whole sample. For instance, in countries for which we have a small number of observations, the industry fixed-effect tends to become, in practice, a firm fixed-effect.
} 


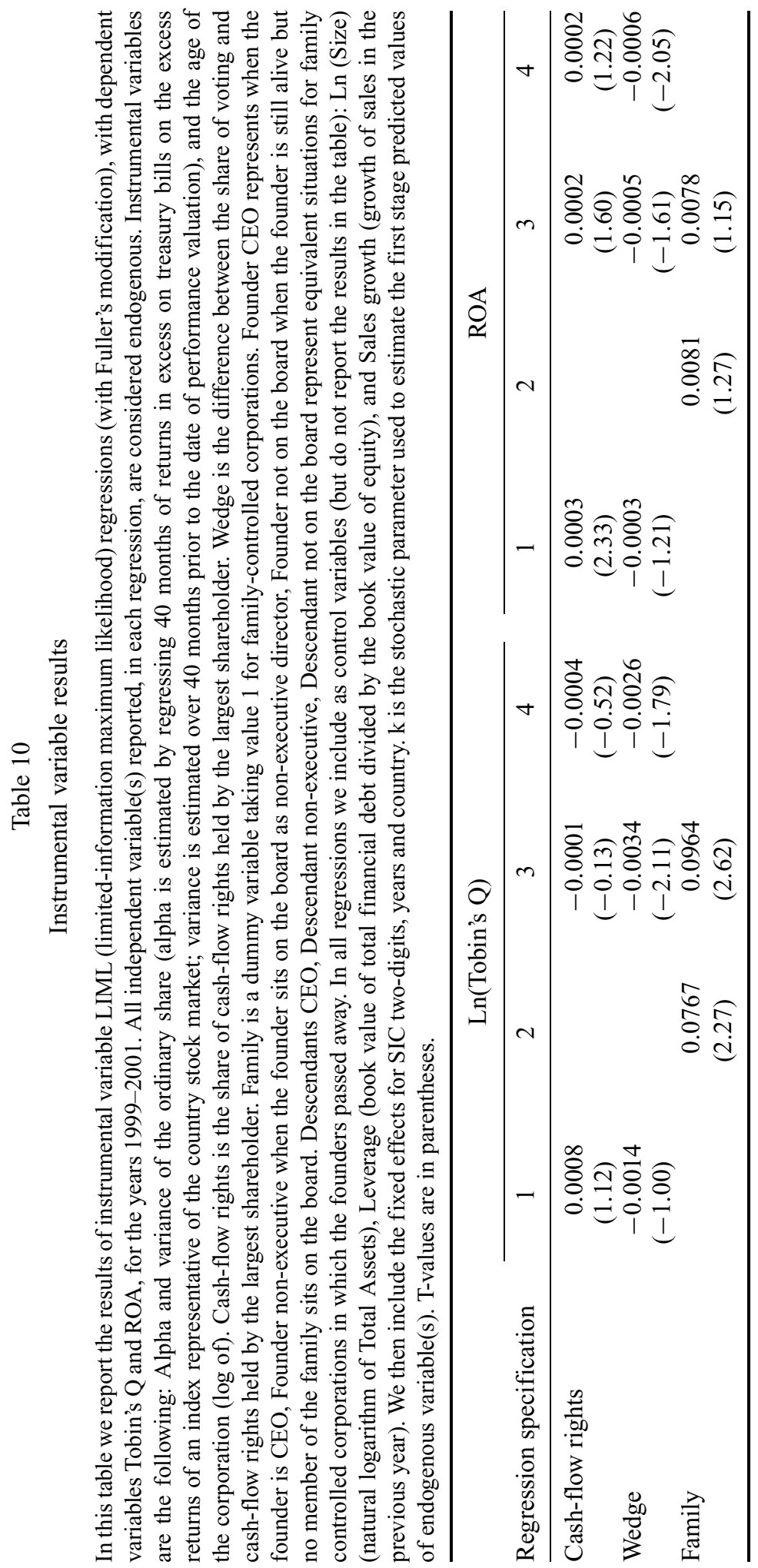




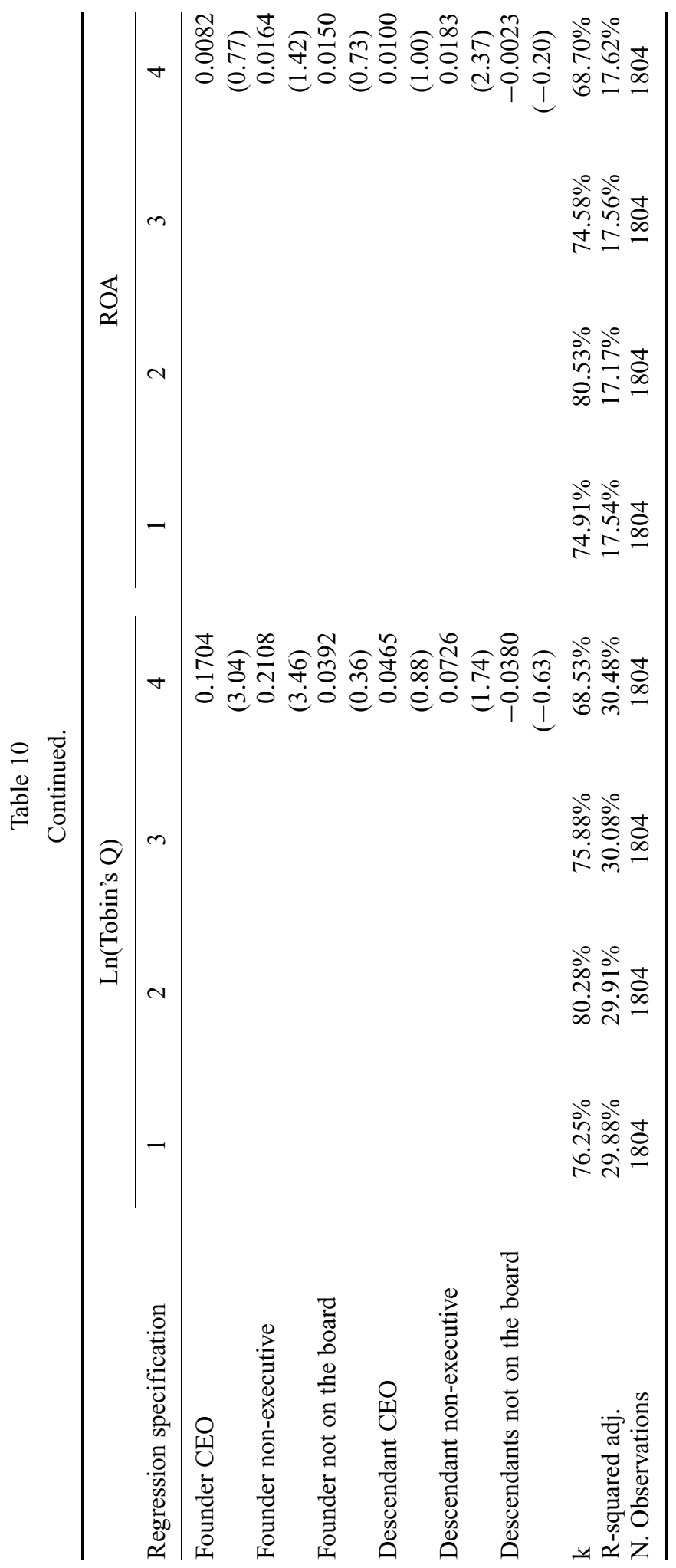




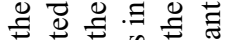

$\because$.

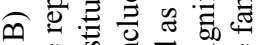

व

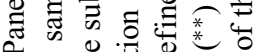

¿

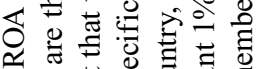

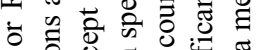

భ. 莺

ब

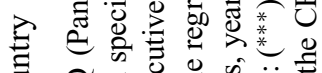

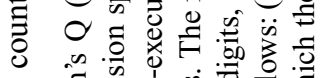

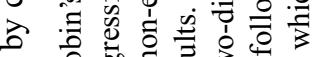

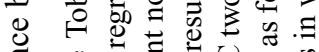

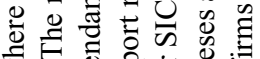

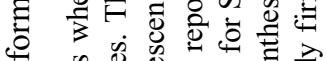

氙

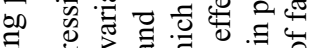

क力口

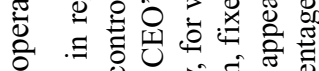

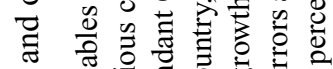

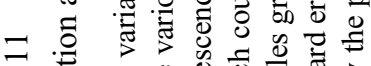

卷

Ð

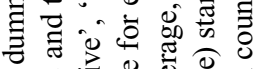

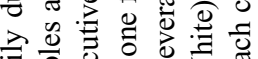

ह 00

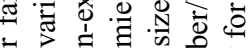

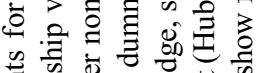

글 氙它

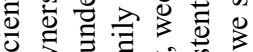

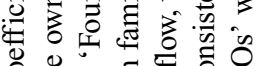

ठ

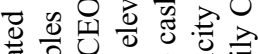

范

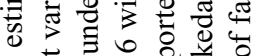

\&

\& $\quad$ 穴

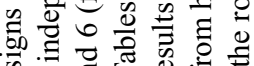

कि. 可

$\notin \Xi \approx \underbrace{\pi}_{0} \Xi$

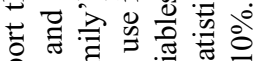

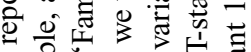

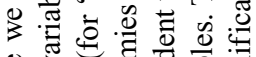

讨羊要

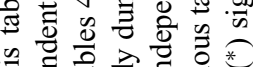

记

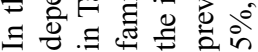

t

(1)

อั๋

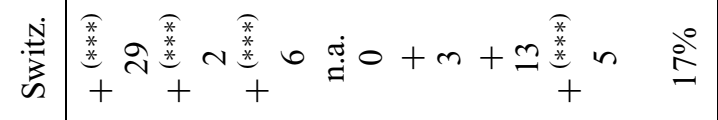

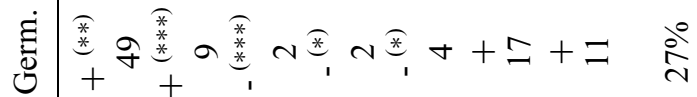

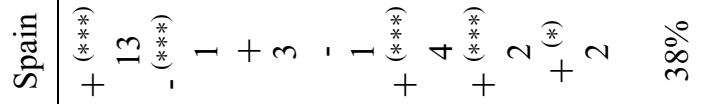

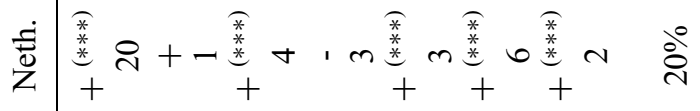

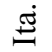

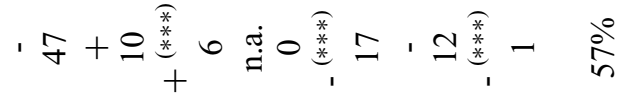

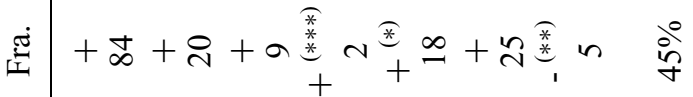

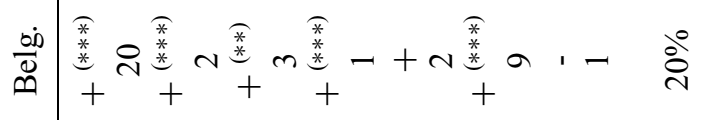

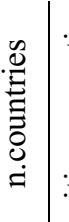

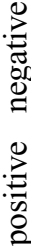

$m-N+\forall m b$

$\infty \sim \infty \sim 6 \infty$

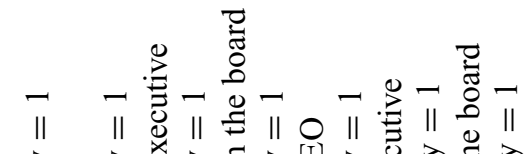

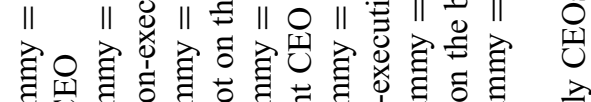

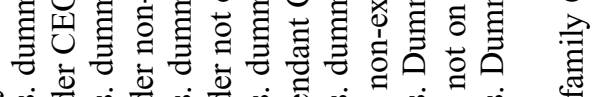

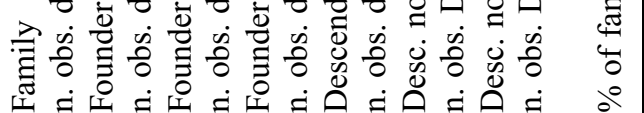




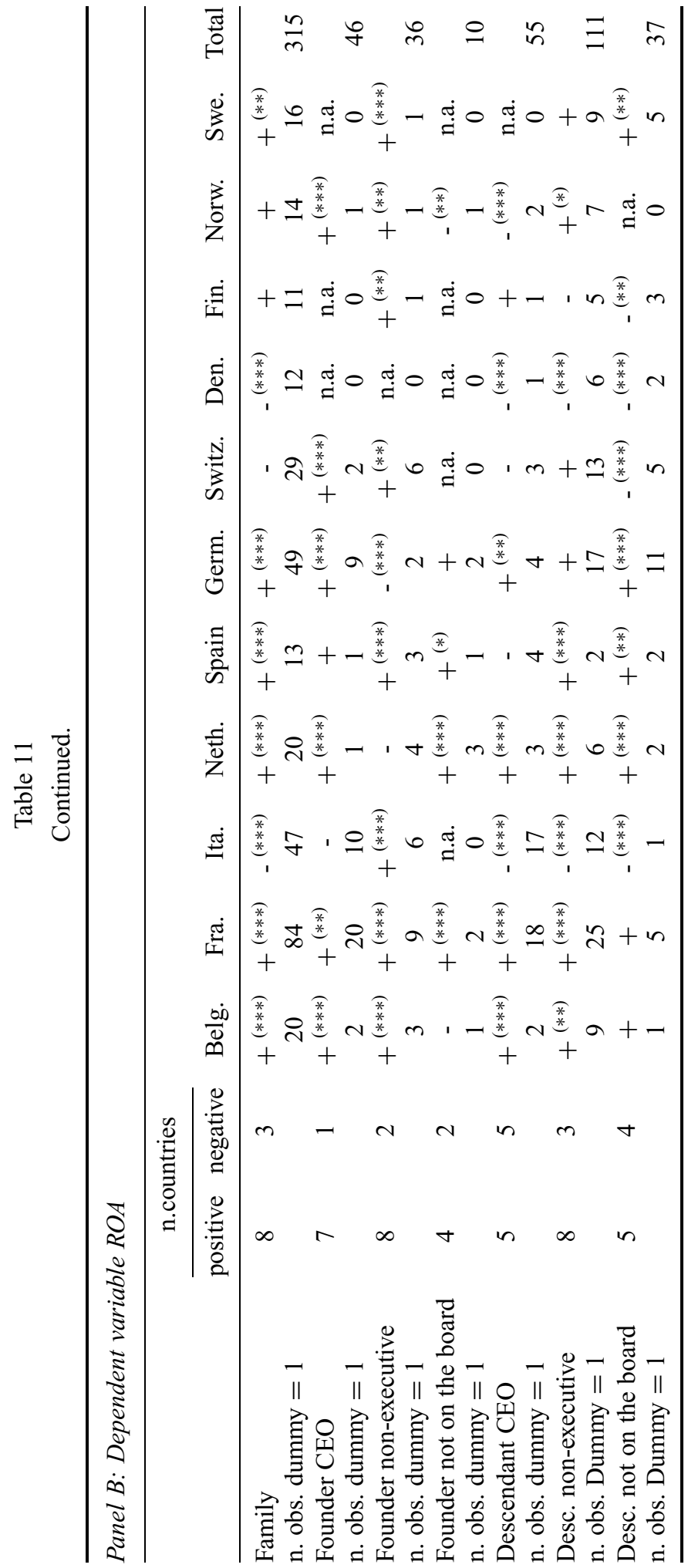


particular, that firms in which the CEO is a descendant are concentrated in France and Italy, given that in these two countries we find 35 cases out of 55 for the whole sample. In French-origin countries it is also uncommon for no family member to sit on the board.

The regression results in Table 11 are in line with those we commented upon when we considered the family effect in continental Europe as a whole, in the sense that the relevant results are actually widespread across countries.

When we look at the regressions in which the simple family-control dummy variable is considered (first line of Panel A and B), we note that in 8 out of 11 countries it always takes a positive sign, as it does in the whole sample (see Table 4). In just two countries - Italy and Denmark - the family effect seems to be negative in both Panels A and B, so that for them we find an unequivocal suggestion that family control negatively affects both market valuation and operating performance. For Switzerland, the effect is positive for market valuation and negative for operating performance, while the reverse is true for Norway.

We then show the results of the regressions in which we split the family effect along both the founder/descendant and the CEO/non-executive dimensions. It is clearly appropriate to be cautious in considering the results of this regression, given that in many countries there are a small number of companies for each case. However, also in this regression, the results at the country level are in line with the evidence for the whole of Europe. The evidence of Tables 5 and 6 showed that there is a large positive effect when the founder is present; and actually the coefficient on the founderCEO dummy is positive in 7 countries out of 8 (not 11 because there is no founder CEO in Sweden, Denmark and Finland) and the coefficient on founder-non-executive is positive in 8 out of 10 (no founder non-executive in Denmark), both when Tobin's Q and when ROA are the independent variable. The evidence of Table 6 then showed that descendant-non-executive firms exhibit better performance than non-family firms, while descendant-CEO firms do not, and actually, in 8 countries out of 11, the descendant-nonexecutive effect is positive for both market valuation and operating performance, while the descendant-CEO effect is positive in only 6 out of 10 countries (no descendant-CEO in Sweden) for market valuation, and in 5 out of 10 for operating performance. Finally, the evidence of Table 6 showed that the case in which members of the family do not sit on the board is the relatively worse case for family firms, and this is confirmed clearly at least by market valuation.

\section{Summary and Conclusion}

In this paper we have highlighted the link existing in continental Europe between corporate performance and ownership structure. European corporations exhibit concentrated ownership structures, a relevant degree of separation between control and cash-flow rights, and widespread diffusion of family control. Family control is clearly associated with the control-enhancing devices that allow separation between control and cash-flow rights.

However, regression analysis of the link between corporate valuation and ownership structure shows that, notwithstanding the negative effect of the more frequent recourse to control-enhancing devices, family control is positive for European corporations. It is highly positive at the founder stage - provided the founder still exerts an active role as CEO or non-executive director - much in the same way as it is in the USA. The different result with respect to the USA, is that the family effect continues to be positive at the 
descendants stage - when descendants limit themselves to non-executives roles - or at least non-negative - when descendants assume the role of CEO. Only when the family is not represented on the board do family-controlled firms seem to perform worse than non-family firms.

We confirm non-European results about the negative effect of control-enhancing devices. However, we show that although control-enhancing devices are associated throughout the world with family control, this does not per se permit the jump to the conclusion of a negative effect of the latter. Outside of the USA, the UK and a few other countries, the majority of listed non-financial corporations are family-controlled, and it is important to reach conclusions about the desirability of this type of control. The continental European evidence tells us that, notwithstanding the frequent preference of family corporations for apparently inefficient ownership structures, the general effect of family control may still be positive.

Finally, our findings suggest an empirical argument of caution - adding to several theoretically-founded points that have been deployed (Berglof and Burkart, 2003) towards the usefulness of a regulation aiming to prohibit separation of control and cashflow rights, of the kind that is currently being debated at the EC level. It is true that separation per se is associated with lower performance. However, separation may have in a number of cases a role in allowing control of subjects who are better able to manage or monitor corporations, whose beneficial skills may more than outweigh the costs of an inefficient ownership structure. Therefore, it is not clear that an abrupt dissolution of existing controlling equilibria would lead to a more efficient European corporate sector.

\section{Appendix A : Data sources}

For all countries: Worldscope and Extel (Thomson financial); Osiris (Bureau Van Dijck); corporations' websites; news searched on Lexis-Nexis and the world wide web (Google search engine).

$\begin{array}{ll}\text { Belgium } & \text { Euronext (www.euronext.com); L'Echo (www.lecho.be). } \\ \text { Denmark } & \text { Copenhagen Stock Exchange (www.cse.dk). } \\ \text { France } & \text { AMF (www.amf-france.org), Euronext (www.euronext.com). } \\ \text { Germany } & \text { Wer gehoert zu wem (Commerzbank), Onvista (www.onvista.de). } \\ \text { Italy } & \text { CONSOB (www.consob.it), Il taccuino dell'azionista (Il Sole 24 Ore } \\ & \text { Libri) }\end{array}$

The Netherlands Euronext (www.euronext.com); Elsevier Ondernemings Rapport (available on Lexis-Nexis).

Spain CNMV (www.cnmv.es).

Switzerland Bilanz on line (www.aktienfuehrer.ch); Guide des Actions suisses (Verlag Finanz und Wirtschaft).

For Finland, Norway and Sweden we do not rely on specific national data sources.

\section{References}

Adams, R., Almeida, H. and Ferreira, D., 'Understanding the relationship between founder-CEOs and firm performance', Working Paper (SSRN, 2004). 
Almeida, H. and Wolfenzon, D., 'A theory of pyramidal ownership and family business groups', Journal of Finance, 2006, forthcoming.

Anderson, R. C. and Reeb, D. M., 'Founding-family ownership and firm performance: evidence from the S\&P 500', Journal of Finance, Vol. 58, 2003, pp. 1301-28.

Anderson, T. W., Kumitomo, N. and Takamitsu, S., 'Evaluation of the distribution function of the limited information maximum likelihood estimator', Econometrica, Vol. 50, 1982, pp. 1009-27.

Barca, F. and Becht, M. (eds), The Control of Corporate Europe (Oxford University Press: 2001).

Berglof, E. and Burkart, M., 'European takeover regulation', Economic Policy, Vol. 18, 2003, pp. 171-213.

Bhattacharya, U. and Ravikumar, B., 'Capital markets and the evolution of family business', Journal of Business, Vol. 74, 2001, pp. 187-220.

Burkart, M., Panunzi, F. and Shleifer, A., 'Family firms', Journal of Finance, Vol. 58, 2003, pp. 2167-2202.

Campbell, J., 'Understanding risk and return', Journal of Political Economy, Vol. 104, 1996, pp. 298-345.

Claessens, S., Djankov, S., Fan, J. P. H. and Lang, L. H. P., 'Disentangling the incentive and entrenchment effects of large shareholdings', Journal of Finance, Vol. 57, 2002, pp. 2741-71.

Claessens, S., Djankov, S. and Lang, L. H. P., 'The separation of ownership and control in East Asian corporations', Journal of Financial Economics, Vol. 58, 2000, pp. 81-112.

Cronqvist, H. and Nilsson, M., 'Agency costs of controlling minority shareholders', Journal of Financial and Quantitative Analysis, Vol. 38, 2003, pp. 695-719.

Demsetz, H. and Lehn, K., 'The structure of corporate ownership: causes and consequences', Journal of Political Economy, Vol. 93, 1985, pp. 1155-77.

Denis, D. J. and Denis, D. K., 'Majority owner-managers and organizational efficiency', Journal of Corporate Finance, Vol. 1, 1994, pp. 91-118.

Ehrhardt, O., Nowak, E. and Weber, F., 'Running in the family - the evolution of ownership, control, and performance in German family-owned firms 1903-2003', Working Paper (Swiss Finance Institute, 2006).

Faccio, M. and Lang, L. H. P., 'The ultimate ownership of Western European corporations', Journal of Financial Economics, Vol. 65, 2002, pp. 365-95.

Faccio, M., Lang, L. H. P. and Young, L., 'Dividends and expropriation', American Economic Review, Vol. 91, 2001, pp. 54-78.

Fahlenbrach, R., 'Founder-CEOs and stock market performance', Working Paper (Ohio State University, 2005).

Gadhoum, Y., Lang, L. H. P. and Young, L., 'Who controls US?', European Financial Management, Vol. 11, 2005, pp. 339-64.

Gompers, P., Ishii, J. and Metrick, A., 'Incentives vs. control: an analysis of US dual-class companies', Working Paper no. 10240 (NBER, 2004)

Gorton, G. and Schmid, F. A., 'Universal banking and the performance of German firms', Journal of Financial Economics, Vol. 58, 2000, pp. 29-79.

Heiss, F. and Köke, J., 'Dynamics in ownership and firm survival: evidence from corporate Germany', European Financial Management, Vol. 10, 2004, pp. 167-96.

Hillier, D. J. and McColgan, P. M. L., 'Firm performance, entrenchment and managerial succession in family firms', Working Paper (2004).

Himmelberg, C. P., Hubbard, G. R. and Palia, D., 'Understanding the determinants of managerial ownership and the link between ownership and performance', Journal of Financial Economics, Vol. 53, 1999, pp. 353-84.

HLG (High Level Group of Company Law Experts), 'Report on issues related to takeover bids', 2002a, available at http://europa.eu.int.

HLG (High Level Group of Company Law Experts), 'Report on a modern regulatory framework for company law in Europe', 2002b, available at http://europa.eu.int.

Huber P. J., Robust Statistics (New York: John Wiley \& Sons, 1981). 
La Porta, R., Lopez-de-Silanes, F. and Shleifer, A., 'Corporate ownership around the world', Journal of Finance, Vol. 54, 1999, pp. 471-518.

Lins, K. V., 'Equity ownership and firm value in emerging markets', Journal of Financial and Quantitative Analysis, Vol. 38, 2003, pp. 159-84.

Maury, B., 'Family ownership and firm performance: empirical evidence from Western European corporations', Journal of Corporate Finance, Vol. 12, 2006, pp. 321-41.

McConnaughy, D., Walker, M., Henderson, G. and Chandra, M., 'Founding family controlled firms: efficiency and value', Review of Financial Economics, Vol. 7, 1998, pp. 1-19.

Morck, R., Shleifer, A. and Vishny, R., 'Alternative mechanisms for corporate control', American Economic Review, Vol. 79, 1989, pp. 842-52.

Morck, R., Strangeland, D. and Yeung, B., 'Inherited wealth, corporate control, and economic growth', in Morck, R. (ed), Concentrated Corporate Ownership (University of Chicago Press, 2000).

Palia, D. and Ravid, S. A., 'The role of founders in large companies: entrenchment or valuable human capital?', Working Paper (Rutgers University, 2002).

Pérez-González, F., 'Inherited control and firm performance' American Economic Review, 2006, forthcoming.

Shleifer, A. and Vishny, R., 'Large shareholders and corporate control', Journal of Political Economy, Vol. 94, 1986, pp. 461-89.

Sraer, D. and Thesmar, D., 'Performance and behaviour of family firms: Evidence from the French stock market', Discussion Paper No. 4520 (CEPR, 2004).

Stock, J. H., Wright, J. H. and Yogo, M., 'A survey of weak instruments and weak identification in generalized method of moments', Journal of Business and Economic Statistics, Vol. 20, 2002, pp. 518-28.

Villalonga, B. and Amit, R., 'How do family ownership, control and management affect firm value?' Journal of Financial Economics, Vol. 80, 2006, pp. 385-417.

Volpin, P., 'Governance with poor investor protection: Evidence from top executive turnover in Italy', Journal of Financial Economics, Vol. 64, 2002, pp. 61-90. 